\title{
Weak Complexes of Sulfur Compounds with Halide Ligands
}

\author{
Salama B. Salama* and Saad Wasif** \\ ${ }^{*}$ Department of Chemistry, College of Science, Sultan Qaboos University, \\ P. O. Box 36, Al Khod 123, Muscat, Sultanate of Oman. \\ ${ }^{*}$ University of Toronto, Canada
}

درلسة لامسقدل بين مركبلت الكبريت ولئيونت الهالوجين

سملامة باوسسلامة وسعد والهف

خلماصة: في خلل الثلاثين علماً الماضية تمت درلمة قفاعلات مركبلت

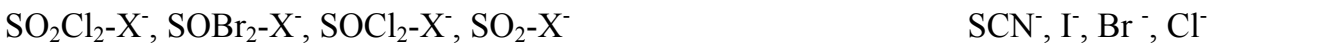

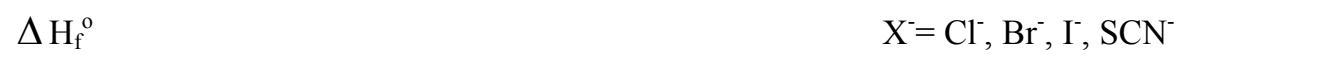

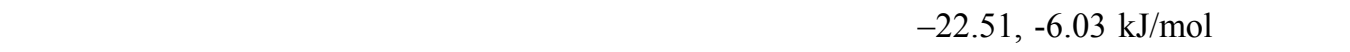

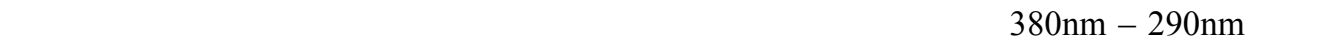

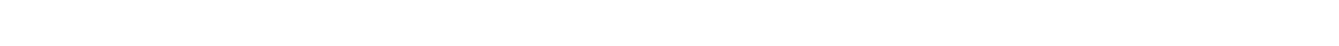

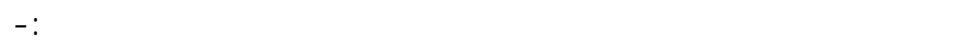

$$
\mathrm{SO}_{2}-\mathrm{I}^{-}+\mathrm{Cl}^{-}=\mathrm{SO}_{2}-\mathrm{Cl}^{-}+\mathrm{I}^{-}
$$

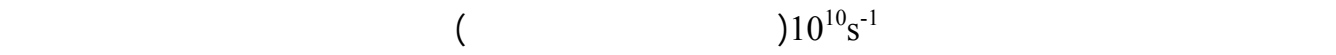

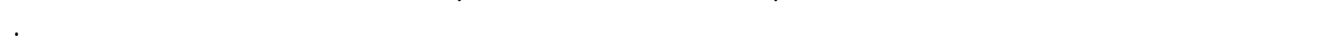

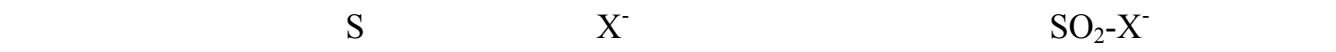

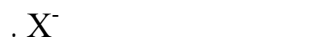

ABSTRACT: This review summarizes the study of the formation of $\mathrm{SO}_{2}-\mathrm{X}^{-}, \mathrm{SOCl}_{2}-\mathrm{X}^{-}$, $\mathrm{SOBr}_{2}-\mathrm{X}^{-}, \mathrm{SO}_{2} \mathrm{Cl}_{2}-\mathrm{X}^{-}$complexes $\left(\mathrm{X}^{-}=\mathrm{Cl}^{-}, \mathrm{Br}^{-}, \mathrm{I}^{-}\right.$, and $\left.\mathrm{SCN}^{-}\right)$in pure and mixed solvents of acetonitrile and dimethylsulfoxide over the past 30 years. Spectrometry $(290 \mathrm{~nm}-380 \mathrm{~nm})$ was the principal technique used for the investigation, since the enthalpies of formation $\Delta \mathrm{H}_{\mathrm{f}}{ }^{0}$ of the above complexes are low $(-6.03--22.51 \mathrm{~kJ} / \mathrm{mol})$. The stability of the complexes depend on the nature of the solvent, acceptor properties of the sulfur compounds, the donor properties of the halide ions and the temperature of the reaction. Also, it was found that the extent of the iodide ion replacement reactions by the other halide depends on the nature of the solvent and the halide ions.

$$
\mathrm{SO}_{2} \mathrm{I}^{-}+\mathrm{X}^{-} \rightarrow \mathrm{SO}_{2}-\mathrm{X}^{-}+\mathrm{I}^{-}
$$

The structures of $\mathrm{SO}_{2}-\mathrm{X}^{-}$compounds are pyramidal, with $\mathrm{X}^{-}$at the top of the pyramid, the $\mathrm{S}$ atom at the center, and the angle depends on the nature of the halide ion. 


\section{SALAMA and WASIF}

\section{CONTENTS}

1. Introduction

2. Detection, Stoichiometry and Stability of $\mathrm{SO}_{2}-\mathrm{X}^{-}, \mathrm{SOCl}_{2}-\mathrm{X}^{-}$, and $\mathrm{SO}_{2} \mathrm{Cl}_{2}-\mathrm{X}^{-}$

Complex Species

2.1 Detection of Sulfur Complex Species 33

2.2 Stoichiometry and Complex Species $\quad 34$

2.3 Stability Constants of Complex Species

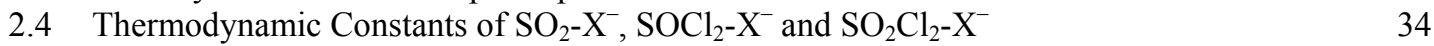

2.5 The Donor-Acceptor Nature of the Complex Species 36

2.6 Correlation of the Order of Stability Constants of Different Complexes

with Donor-Acceptor Properties

$\begin{array}{ll}\text { 3. Solvent Effects on Stability of } \mathrm{SO}_{2}-\mathrm{X}^{-}, \mathrm{SOCl}_{2}-\mathrm{X}^{-} \text {and } \mathrm{SO}_{2} \mathrm{Cl}_{2}-\mathrm{X}^{-} & 38 \\ 3.1 \text { Pure Solvents } & 38\end{array}$

3.2 Mixed Solvents: (MeCN-dmso)

3.3 The $\mathrm{SO}_{2}-\mathrm{X}^{-}$Species $\quad 40$

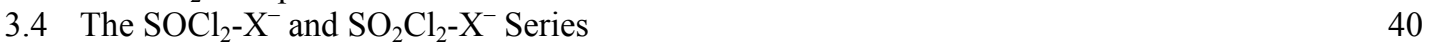

$\begin{array}{lll}3.5 & \text { Vertical Correlations in Table } 9 & 41\end{array}$

3.5.1 The Iodide Complex Series $\quad 41$

3.5.2 The Bromide and Chloride Complex Series $\quad 41$

$\begin{array}{ll}3.6 & \text { Evidence for Solvent-Solvent Interactions }\end{array}$

3.6.1 Spectroscopic 41

3.6.2 Vapor-Pressure, Viscosity, and Excess Functions from Refractive
Index, Dielectric Constant and Volume

3.7 A Thermodynamic View of Solvent Effects on The Stability of $\mathrm{SO}_{2}-\mathrm{X}^{-}$, $\mathrm{SOCl}_{2}-\mathrm{X}^{-}$and $\mathrm{SO}_{2} \mathrm{Cl}_{2}-\mathrm{X}^{-} \quad 44$

3.7.1 The Significance of $\Delta \mathrm{G}_{\mathrm{f}}{ }^{\mathrm{o}}$ of Complexes in Relation to Solute-Solvent
Interactions

3.7.2 The Dependence of $\Delta \mathrm{H}_{\mathrm{f}}{ }^{o}$ and $\Delta \mathrm{S}_{\mathrm{f}}{ }^{\circ}$ of Complex Species on Solvent
Composition $\begin{array}{ll}\text { Composition } & 45 \\ \text { acement Reactions } & 46\end{array}$

$\begin{array}{lr}\text { 4. Ligand Replacement Reactions } & 46 \\ 4.1 \text { Correlation of Stability Constants with Ligand Replacement } & 48\end{array}$

4.1.1 The $\mathrm{Cl}^{-}-\mathrm{I}^{-}$Reaction $\quad 48$

4.1.2 ${\mathrm{The} \mathrm{Br}^{-}-\mathrm{I}^{-} \text {and } \mathrm{SCN}^{-}-\mathrm{I}^{-} \text {Reactions }}_{49}$

4.2 The Role of Solvents in Replacement Reactions $\quad 49$

4.3 Replacement Reactions in Mixed Solvents $\quad 50$

5. Structure of $\mathrm{SO}_{2}-\mathrm{X}^{-} \quad 50$

6. Conclusion $\quad 51$

$\begin{array}{ll}\text { 7. References } & 51\end{array}$

\section{Introduction}

Throughout the past 30 years there has been a growing interest in the field of sulfur compoundshalide ligands chemistry. The motivation for this interest has undoubtedly arisen from various sources. Witeckowa and Witok (1955) investigated the reaction between $\mathrm{SO}_{2}$ and iodine in the gas phase and in solutions by spectrophotometric and kinetic techniques. They suggested that the interaction between HI and $\mathrm{SO}_{2}$ in aqueous solutions is due to dipole-dipole interaction. Burke and Smith (1959) studied the molecular complexes between $\mathrm{HF}$ and $\mathrm{SO}_{2}$ by infrared spectroscopy. Jander and Tuerk $(1962 ; 1963)$ studied the adduct of iodine with $\mathrm{H}_{2} \mathrm{~S}$ in dichloroethane at $-95^{\circ} \mathrm{C}$. The low enthalpy of formation $\left(\Delta \mathrm{H}_{\mathrm{f}}^{\mathrm{o}}=-31.8 \mathrm{~kJ}\right.$ $/ \mathrm{mol}$ ) was taken as indication of the charge transfer nature of the adduct formation. Burow (1970) studied 


\section{WEAK COMPLEXES OF SULFUR COMPOUNDS}

the solvate formation between $\mathrm{SO}_{2}$ and $\mathrm{Cl}^{-}, \mathrm{Br}^{-}$, and $\mathrm{I}^{-}$ligands in liquid $\mathrm{SO}_{2}$. Gutmann (1956) isolated a number of adducts of $\mathrm{SOCl}_{2}$ and $\mathrm{SO}_{2} \mathrm{Cl}_{2}$ with halide ligands. Sandhu et al $(1960 ; 1962)$ discussed the tendency of $\mathrm{SO}_{2} \mathrm{Cl}_{2}$ to form adducts with Lewis acids and Lewis bases. Salama and Wasif et al (1971; $1973 ; 1994)$ studied the interaction of some organic sulfur compounds and $\mathrm{SO}_{2}, \mathrm{SOCl}_{2}, \mathrm{SO}_{2} \mathrm{Cl}_{2}$, \& $\mathrm{SOBr}_{2}$ with $\mathrm{Cl}^{-}, \mathrm{Br}^{-}, \mathrm{I}^{-}$, and $\mathrm{SCN}^{-}$ligands in acetonitrile $(\mathrm{MeCN})$, dimethylsulfoxide (dmso) and water (for $\mathrm{SO}_{2}$ species only).

The collated data are summarized in four parts:

2. Detection, stoichiometry and stability of $\mathrm{SO}_{2}-\mathrm{X}^{-}, \mathrm{SOCl}_{2}-\mathrm{X}^{-}$, and $\mathrm{SO}_{2} \mathrm{Cl}_{2}-\mathrm{X}^{-}$complex species.

3. Effects of solvents on the stability of complex species.

4. Ligand replacement reactions in complex species and factors which affect them.

5. Structure of $\mathrm{SO}_{2}-\mathrm{X}^{-}$species.

\section{Detection, Stoichiometry and Stability of $\mathrm{SO}_{2}-\mathrm{X}^{-}, \mathrm{SOCl}_{2}-\mathrm{X}^{-}$, and $\mathrm{SO}_{2} \mathrm{Cl}_{2}-\mathrm{X}^{-} \mathrm{Complex}$ Species}

\subsection{Detection of Sulfur Complex Species}

Figure 1 shows the absorbance peaks of mixtures of $\mathrm{SO}_{2}$ with (A) tetramethylammonium iodide, (B) tetramethylammonium bromide and $(\mathrm{C})$ tetramethylammonium chloride. Table 1 includes the absorbance peaks of sulfur compounds, $\mathrm{SO}_{2}, \mathrm{SOCl}_{2}$ and $\mathrm{SO}_{2} \mathrm{Cl}_{2}$ with tetramethylammonium halides in which the halide was in abundance of the sulfur compound and in acetonitrile $(\mathrm{MeCN})$ solvent. Similar peaks were obtained in dmso and water confirming earlier studies (Jander et al., 1937; Seel et al., 1955).

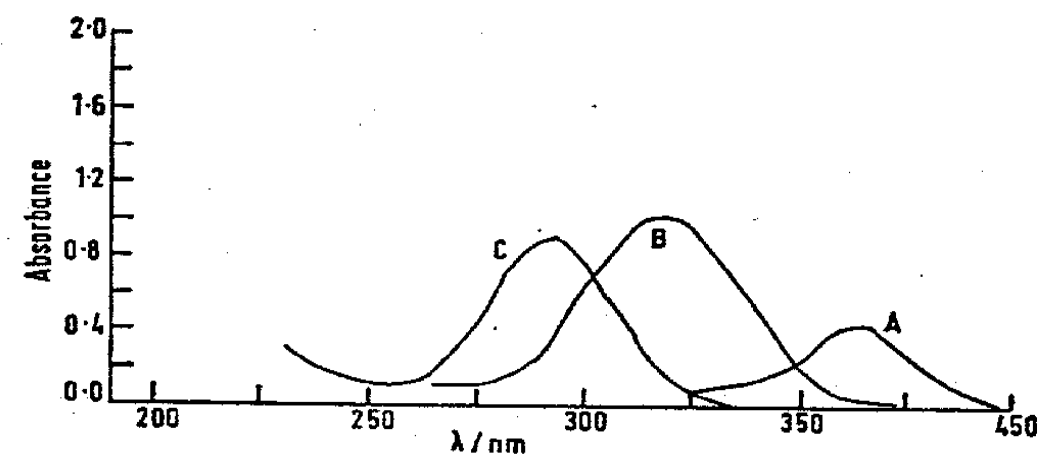

Figure 1. Absorbance peaks of $\mathrm{SO}_{2}-\mathrm{X}^{-}$Species.

Table 1. $\lambda_{\max }$ in $\mathrm{MeCN}$ at $298^{\circ} \mathrm{K}$

\begin{tabular}{|c|l|l|l|}
\hline Sulfur compound & \multicolumn{3}{|c|}{$\mathrm{S}+\mathrm{X}^{-}$} \\
\hline$(\mathrm{S})$ & $\mathrm{Cl}^{-}$ & $\mathrm{Br}^{-}$ & $\mathrm{I}^{-}$ \\
\hline $\mathrm{SO}_{2}(280) \mathrm{nm}$ & 292 & 320 & 380 \\
$\mathrm{SOCl}_{2}(280)$ & 292 & 322 & 382 \\
$\mathrm{SO}_{2} \mathrm{Cl}_{2}(275)$ & 293 & 322 & 375 \\
\hline
\end{tabular}




\section{SALAMA and WASIF}

\subsection{Stoichiometry and Complex Species}

Job's (1928) and Asmus's (1960) methods were used to determine the complex stoichiometry. The former gave the empirical formula while the latter gave its molecular formula. The two methods showed that all complex species were of 1:1 type irrespective of the solvent used (MeCN or dmso).

\subsection{Stability Constants of Complex Species}

If the complex formation is represented by the equations

$$
\begin{array}{rlll}
\mathrm{SO}_{2}+\mathrm{X}^{-} & = & \mathrm{SO}_{2}-\mathrm{X}^{-} & (1) \\
\mathrm{SOCl}_{2}+ & \mathrm{X}^{-} & = & \mathrm{SOCl}_{2}-\mathrm{X}^{-} \\
\mathrm{SO}_{2} \mathrm{Cl}_{2}+ & \mathrm{X}^{-} & (2) \\
\mathrm{S} \text { compound } & = & \mathrm{SO}_{2} \mathrm{Cl}_{2}-\mathrm{X}^{-} & (3) \\
\text { Halide Ligand } & = & \text { Complex Species }
\end{array}
$$

then the equilibrium constants for reactions (1) - (3), which will be defined throughout this article as stability constants, may be represented by the equation

$$
\mathrm{K}_{\mathrm{c}}=[\text { Complex }] /[\mathrm{S} \text { compound }]\left[\mathrm{X}^{-}\right]
$$

where the parentheses represent molar concentration of each species and $\mathrm{K}_{\mathrm{c}}$ is defined by the units $\mathrm{dm}^{3}$ $\mathrm{mol}^{-1}$. The magnitude (or value) of $\mathrm{K}_{\mathrm{c}}$ is taken as a measure of the ability of the reacting species to associate in a complex.

Spectrophotometry was the principal technique used to find the concentration of all the terms in equation (4). Two procedures (Salama et al., 1971) were adopted to evaluate $\mathrm{K}_{\mathrm{c}}$ : (a) graphical and (b) by calculation from the molar concentrations of reactants and products. Both methods (a \& b) depend on the absorbances of individual species before and after they are mixed together. Table 2 (Salama et al., 1971) includes $\mathrm{K}_{\mathrm{c}}$ values for $\mathrm{SO}_{2}-\mathrm{X}^{-}, \mathrm{SOCl}_{2}-\mathrm{X}^{-}$and $\mathrm{SO}_{2} \mathrm{Cl}_{2}-\mathrm{X}^{-}$in $\mathrm{MeCN}$ at $293^{\circ}$ or $298^{\circ} \mathrm{K}$.

In most cases the difference between $\mathrm{K}_{\mathrm{c}}$ values by the graphical and calculation methods does not exceed $5 \%$ which may be taken as the limit of the experimental error. The constancy of the $\mathrm{K}_{\mathrm{c}}$ data is further evidence to confirm that all the complex species were of a 1:1 type (Salama et al., 1971).

Table 2. Stability Constants of $\mathrm{SO}_{2}-\mathrm{X}^{-}, \mathrm{SOCl}_{2}-\mathrm{X}^{-}$and $\mathrm{SO}_{2} \mathrm{Cl}_{2}-\mathrm{X}^{-}$in $\mathrm{MeCN}$ at $293^{\circ}$ or $298^{\circ} \mathrm{K}$

\begin{tabular}{|c|c|c|c|c|c|c|c|c|c|}
\hline S Compound & \multicolumn{3}{|c|}{$\mathrm{SO}_{2}$} & \multicolumn{3}{c|}{$\mathrm{SOCl}_{2}$} & \multicolumn{3}{c|}{$\mathrm{SO}_{2} \mathrm{Cl}_{2}$} \\
\hline Halide ligand & $\mathrm{I}^{-}$ & $\mathrm{Br}^{-}$ & $\mathrm{Cl}^{-}$ & $\mathrm{I}^{-}$ & $\mathrm{Br}^{-}$ & $\mathrm{Cl}^{-}$ & $\mathrm{I}^{-}$ & $\mathrm{Br}^{-}$ & $\mathrm{Cl}^{-}$ \\
\hline $\mathrm{K}_{\mathrm{c}}($ Graphical $)$ & 37.9 & 192 & 348 & 152 & 242 & 367 & 78 & 40.6 & 10.6 \\
\hline $\mathrm{K}_{\mathrm{c}}$ (Calculation) & 38.5 & 190 & 363 & 150 & 241 & 362 & 77 & 41 & 10.2 \\
\hline Temp. ${ }^{\circ} \mathrm{K}$ & 298 & 293 & 293 & 298 & 298 & 298 & 298 & 298 & 298 \\
\hline
\end{tabular}

\subsection{Thermodynamic Constants of $\mathrm{SO}_{2}-\mathrm{X}^{-}, \mathrm{SOCl}_{2}-\mathrm{X}^{-}$and $\mathrm{SO}_{2} \mathrm{Cl}_{2}-\mathrm{X}^{-}$}

Table 3 includes $\mathrm{K}_{\mathrm{c}}$ data for $\mathrm{SO}_{2}-\mathrm{X}^{-}, \mathrm{SOCl}_{2}-\mathrm{X}^{-}$and $\mathrm{SO}_{2} \mathrm{Cl}_{2}-\mathrm{X}^{-}$over a range of temperatures and their relevant thermodynamic constants. The data in Table 3 point to a weak association between the sulfur compounds (electron acceptors) and the halide ligands (electron donors) of a charge transfer nature (Salama 


\section{WEAK COMPLEXES OF SULFUR COMPOUNDS}

et al., 1971; Ketelaar et al., 1952; Benesi et al., 1949; Drago, 1959; Rossotti et al., 1969; Andrew et al., 1961). Since the solvents used are polar, they possess varying tendencies to solvate the species in solution ( ions, molecules and complex species) and although we are mainly concerned with complex species in acetonitrile, yet a simple interpretation of such enthalpy data will be complicated by solvation and/or dipole interaction. Comparison of the enthalpy data for the different complex species in Table 4 cannot lead to linear correlations.

Table 3. Thermodynamic Constants of $\mathrm{SO}_{2}-\mathrm{X}^{-}, \mathrm{SOCl}_{2}-\mathrm{X}^{-}$and $\mathrm{SO}_{2} \mathrm{Cl}_{2}-\mathrm{X}^{-}$in $\mathrm{MeCN}$

\begin{tabular}{|l|l|c|c|c|}
\hline $\begin{array}{c}\text { Complex } \\
\text { Species }\end{array}$ & \multicolumn{1}{|c|}{$\mathbf{K}_{\mathbf{c}} \mathbf{d m}^{\mathbf{3}} \mathbf{m o l}^{\mathbf{- 1}}$} & $\begin{array}{c}-\Delta \mathbf{G}_{\mathbf{f}}^{\mathbf{0}} \\
\mathbf{k J} / \mathbf{m o l}\end{array}$ & $\begin{array}{c}-\Delta \mathbf{H}_{\mathbf{f}}^{\mathbf{0}} \\
\mathbf{k J} / \mathbf{m o l}\end{array}$ & $\begin{array}{c}-\Delta \mathbf{S}_{\mathbf{f}}^{\mathbf{0}} \\
\mathbf{J} / \mathbf{K} / \mathbf{m o l}\end{array}$ \\
\hline $\mathbf{S O}_{2}-\mathbf{I}^{-}$ & $37.9(298), 34.4(303), 30.8(308)$ & 8.99 & 17.5 & 28.5 \\
\hline $\mathbf{S O}_{2}-\mathbf{B r}^{-}$ & $260(283), 192(293), 137(303)$ & 12.7 & 22.4 & 32.8 \\
\hline $\mathbf{S O}_{2}-\mathbf{C l}^{-}$ & $519(284), 400(293), 348(303)$ & 14.7 & 15.1 & 1.34 \\
\hline $\mathbf{S O C l}_{2}-\mathbf{I}^{-}$ & $190(288), 150(298)$ & 12.2 & 16.9 & 15.1 \\
\hline $\mathbf{S O C l}_{2}-\mathbf{B r}^{-}$ & $276(288), 241(298)$ & 13.6 & 9.82 & -12.6 \\
\hline $\mathbf{S O C l}_{\mathbf{2}}-\mathbf{C l}^{-}$ & $447(288), 362(298), 264(308)$ & 14.6 & 15.4 & 2.72 \\
\hline $\mathbf{S O}_{\mathbf{2}} \mathbf{C l}_{2}-\mathbf{I}^{-}$ & $86(288), 77(298), 71(308)$ & 10.8 & 6.01 & -15.9 \\
\hline $\mathbf{S O}_{2} \mathbf{C l}_{2}-\mathbf{B r}^{-}$ & $45(288), 39(298), 37(308)$ & 9.20 & 10.7 & 4.98 \\
\hline $\mathbf{S O}_{\mathbf{2}} \mathbf{C l}_{2}-\mathbf{C l}^{-}$ & $12(288), 10.5(298), 9.3(308)$ & 5.76 & 7.82 & 6.90 \\
\hline
\end{tabular}

Of the components taking part in the formation of these complexes only the acceptors (sulfur compounds) have UV absorption peaks, $\mathrm{SO}_{2}(280 \mathrm{~nm}), \mathrm{SOCl}_{2}(280 \mathrm{~nm})$ and $\mathrm{SO}_{2} \mathrm{Cl}_{2}$ (275nm) (Friedman, 1967). The appearance of new peaks due to the formation of the complex species arises from donoracceptor interactions. These result in spectral shifts for the acceptor which must be a function of the donor character of each halide ligand. An attempt was made to correlate such spectral shifts with the reversible potential for:

$$
\mathrm{e}^{-}+\mathrm{X}=\mathrm{X}^{-}
$$

Table 4. Stability Constants of $\mathrm{SO}_{2}-\mathrm{X}^{-}, \mathrm{SOCl}_{2}-\mathrm{X}^{-}$, and $\mathrm{SO}_{2} \mathrm{Cl}_{2}-\mathrm{X}^{-}$in $\mathrm{MeCN}$ at $298^{\circ} \mathrm{K}$

\begin{tabular}{|l|c|c|c|}
\hline & $\mathrm{Cl}^{-}$ & $\mathrm{Br}^{-}$ & $\mathrm{I}^{-}$ \\
\hline $\mathrm{SO}_{2}-\mathrm{X}^{-}$ & 372 & 160 & 38 \\
\hline $\mathrm{SOCl}_{2}-\mathrm{X}^{-}$ & 362 & 241 & 150 \\
\hline $\mathrm{SO}_{2} \mathrm{Cl}_{2}-\mathrm{X}^{-}$ & 10.5 & 41.0 & 77 \\
\hline
\end{tabular}

The linear plots of Figure 2 supplement this assumption for the different species. 


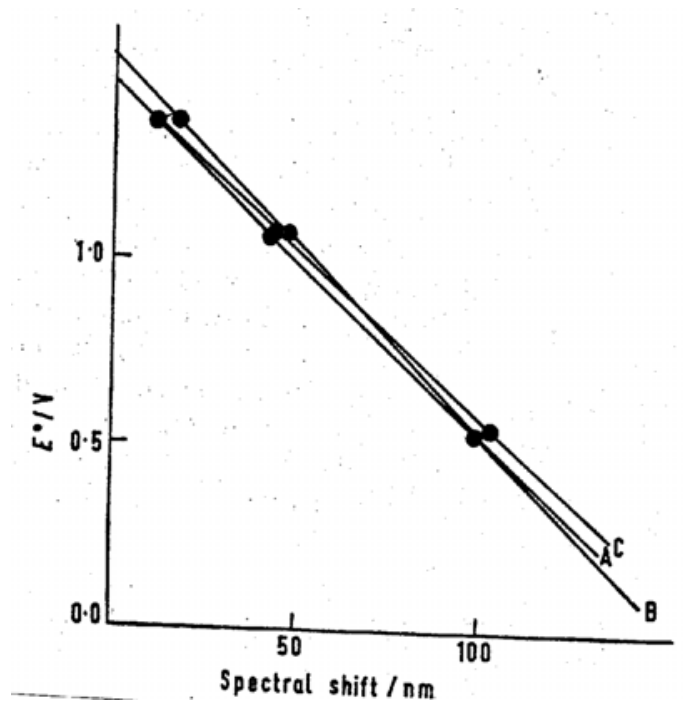

Figure 2. Correlation of $E^{o}$ for the Reaction $\mathrm{e}^{-}+\mathrm{X} \Leftrightarrow \mathrm{X}^{-}$with Acceptor Spectral Shifts: $\mathrm{A}, \mathrm{SO}_{2}-\mathrm{X}^{-}$; $\mathrm{B}, \mathrm{SO}_{2} \mathrm{Cl}_{2}-\mathrm{X}^{-} ; \mathrm{C}, \mathrm{SOCl}_{2}-\mathrm{X}^{-}$

\subsection{The Donor-Acceptor Nature of the Complex Species}

In order to understand the nature of these complexes we shall try to rationalize the stability constants data of Table 4 with the nature of the halide ligands (donors) and the sulfur compounds (acceptors). Table 5 summarizes some important trends (Basolo et al., 1958 ; Gould, 1960).

Table 5. Physical Constants of Halide Ions.

\begin{tabular}{|c|c|c|c|}
\hline & $\mathrm{Cl}^{-}$ & $\mathrm{Br}^{-}$ & $\mathrm{I}^{-}$ \\
\hline Ionisation Potential $(\mathrm{kJ} / \mathrm{mol})$ & 1251 & 1136 & 1000 \\
\hline Electron Affinity $(\mathrm{kJ} / \mathrm{mol})$ & 349 & 325 & 295 \\
\hline${\text { Hydration Energy of } \mathrm{X}^{-} \mathrm{kJ} \text { g-ion }}^{-1}$ & 356 & 310 & 255 \\
\hline Polarisability/Å & 2.3 & 3.3 & 5.1 \\
\hline Electronegativity & 2.83 & 2.74 & 2.21 \\
\hline
\end{tabular}

The iodide ion with high polarisability, low electronegativity and easy oxidation is considered to be a soft Lewis base (Pearson, 1963; Day et al., 1969). The chloride ion with low polarisability and high electronegativity is a hard Lewis base. The bromide ion is a borderline Lewis base. The acceptors include $\mathrm{SO}_{2}$ and $\mathrm{SOCl}_{2}$ in which the oxidation state of sulfur is four and $\mathrm{SO}_{2} \mathrm{Cl}_{2}$ in which it is six. $\mathrm{SO}_{2}$ is a borderline Lewis acid (Pearson, 1963; Day et al., 1969). It acts as a base toward $\mathrm{BF}_{3}$ to form the adduct $\mathrm{SO}_{2}-\mathrm{BF}_{3}$ and as acid towards water. Thionyl chloride $\mathrm{SOCl}_{2}$ is similar to $\mathrm{SO}_{2}$ in that it has a lone pair of electrons $\left(3 \mathrm{~s}^{2}\right)$ but one of the double bonded oxygen atoms is replaced by two $\mathrm{Cl}$ atoms. The $\mathrm{S}-\mathrm{Cl}$ bond is more polarized than the S-O bond owing to the higher electronegativity of $\mathrm{Cl}^{-}$, and would be expected to act as a stronger Lewis acid than $\mathrm{SO}_{2}$, or a better acceptor. Sulphonyl chloride $\mathrm{SO}_{2} \mathrm{Cl}_{2}$, may be related to $\mathrm{SO}_{3}$ (known as a hard Lewis acid) (Pearson, 1963; Day et al., 1969) in the same manner as $\mathrm{SOCl}_{2}$ is related to 


\section{WEAK COMPLEXES OF SULFUR COMPOUNDS}

$\mathrm{SO}_{2}$, and the order of acid strength is $\mathrm{SO}_{2} \mathrm{Cl}_{2}>\mathrm{SOCl}_{2}>\mathrm{SO}_{2}$. The formation of the present complex species is the result of acid-base interactions between the acceptors and the donors and the order of stability given in Table 4 can be discussed on this basis.

\subsection{Correlation of the Order of Stability Constants of Different Complexes with Donor-Acceptor Properties}

Table 4 shows that the stability of $\mathrm{SO}_{2}-\mathrm{X}^{-}$species falls in the order $\mathrm{SO}_{2}-\mathrm{Cl}^{-}>\mathrm{SO}_{2}-\mathrm{Br}^{-}>\mathrm{SO}_{2}-\mathrm{I}^{-}$. Sulfur (IV) forms coordination compounds owing to the electrofilic and nucleofilic nature of the sulfur atom. The former is due to the availability of the empty $3 d$ electron orbitals and the latter to the presence of a lone pair of $3 \mathrm{~s}^{2}$ electrons on the sulfur atom. Thus, in such compounds as $\mathrm{SO}_{2}$, sulfur acts as a $\sigma$-donor only or a $\Pi$-acceptor. However, the donor-acceptor properties of the sulfur atom are exhibited almost synonymously. If the donor (or ligand) contains $d$-orbitals of the appropriate symmetry (i.e. not diffuse) back-donation from the sulfur atom to the donor may occur, giving rise to the $d-d$ multiple bonding which will strengthen the ligand acceptor bond. The $\mathrm{Cl}^{-}$and $\mathrm{Br}^{-}$ions may accept back-donation but this seems doubtful for the $\mathrm{I}^{-}$ion because the $d$-orbitals become progressively diffuse and less available for backdonation as we go down the halide group. The order of complex stability can be explained on this basis.

This interpretation of the stability constants order is supplemented by the classification of the halide ions as hard $\left(\mathrm{Cl}^{-}\right)$borderline $\left(\mathrm{Br}^{-}\right)$and soft $\left(\mathrm{I}^{-}\right)$bases and of $\mathrm{SO}_{2}$ as a borderline Lewis acid. The order of stability of the $\mathrm{SO}_{2}-\mathrm{X}^{-}$complex species would follow the strength of the base and $\mathrm{SO}_{2}-\mathrm{Cl}^{-}$species would be the strongest and $\mathrm{SO}_{2}-\mathrm{I}^{-}$the weakest, as actually found. We may now consider the $\mathrm{SOCl}_{2}-\mathrm{X}^{-}$species. Table 6 includes the ratios of stability constants of $\mathrm{SO}_{2}-\mathrm{X}^{-}$and $\mathrm{SOCl}_{2}-\mathrm{X}^{-}$species.

Table 6. Stability Constants Ratios for $\mathrm{SO}_{2}-\mathrm{X}^{-}$and $\mathrm{SOCl}_{2}-\mathrm{X}^{-}$in $\mathrm{MeCN}$

\begin{tabular}{|c|c|c|c|}
\hline & $\mathbf{I}^{-}$ & $\mathbf{B r}^{-}$ & $\mathbf{C l}^{-}$ \\
\hline $\mathrm{K}_{\mathrm{c}}\left(\mathrm{SO}_{2}-\mathrm{X}^{-}\right) / \mathrm{K}_{\mathrm{c}}\left(\mathrm{SO}_{2}-\mathrm{I}^{-}\right)$ & 1.0 & 4.0 & 10.0 \\
\hline $\mathrm{K}_{\mathrm{c}}\left(\mathrm{SOCl}_{2}-\mathrm{X}^{-}\right) / \mathrm{K}_{\mathrm{c}}\left(\mathrm{SOCl}_{2} \mathrm{I}^{-}\right)$ & 1.0 & 1.6 & 2.4 \\
\hline
\end{tabular}

Table 4 shows that the order of stability of $\mathrm{SOCl}_{2}-\mathrm{X}^{-}$species is similar to that of $\mathrm{SO}_{2}-\mathrm{X}^{-}$where $\mathrm{Cl}^{-}>$ $\mathrm{Br}^{-}>\mathrm{I}^{-}$. Table 6 shows that the stability constants of $\mathrm{SO}_{2}-\mathrm{Cl}^{-}$and $\mathrm{SOCl}_{2}-\mathrm{I}^{-}$are nearly of the same order of magnitude but $\mathrm{K}_{\mathrm{c}}\left(\mathrm{SOCl}_{2}-\mathrm{I}^{-}\right)$is merely 4 times greater than $\mathrm{K}_{\mathrm{c}}\left(\mathrm{SO}_{2}-\mathrm{I}^{-}\right)$and $\mathrm{K}_{\mathrm{c}}\left(\mathrm{SOCl}_{2}-\mathrm{Br}^{-}\right)$and $\mathrm{K}_{\mathrm{c}}\left(\mathrm{SOCl}_{2}-\right.$ $\left.\mathrm{Cl}^{-}\right)$are only 1.6 and 2.4 times greater than $\mathrm{K}_{\mathrm{c}}\left(\mathrm{SOCl}_{2}-\mathrm{I}^{-}\right)$which calls attention to new factors responsible for the observed change in ratios.

The order of stability constants ratio of $\mathrm{SOCl}_{2}-\mathrm{X}^{-}$species shows that as in the case of $\mathrm{SO}_{2}-\mathrm{X}^{-}$the chloride species is the most stable and the iodide is the least stable. This order suggests that the nature of association between the $\mathrm{Cl}^{-}$and $\mathrm{SO}_{2}$ is much the same as with $\mathrm{SOCl}_{2}$. Back-donation may be considered to be the factor contributing to the stability of $\mathrm{SOCl}_{2}-\mathrm{X}^{-}$species. In $\mathrm{SOCl}_{2}$ the electrophilic nature is enhanced over $\mathrm{SO}_{2}$ by the replacement of one oxygen atom by two chlorine atoms and the d-orbitals of sulfur are more exposed for coordination because the electron cloud is removed by the electronegative chlorine atoms, and this makes $\mathrm{SOCl}_{2}$ a better Lewis acid than $\mathrm{SO}_{2}$.

Although the halide ions were classified by Pearson (1963) as Lewis bases of varying strengths and such classification could account for the order of stabilities of $\mathrm{SO}_{2}-\mathrm{X}^{-}$species, the situation may be different with $\mathrm{SOCl}_{2}$. The increased acceptor character does not appear to have changed or to have affected dramatically the nature of association with the $\mathrm{Cl}^{-}$ligand. For the $\mathrm{I}^{-}$ligand this increased acid character appears to have increased the basicities of the $\mathrm{I}^{-}$and $\mathrm{Br}^{-}$ligands relative to that of the $\mathrm{Cl}^{-}$, so $\mathrm{SOCl}_{2}$ appears to be leveling up the basic character of the $\mathrm{I}^{-}$and $\mathrm{Br}^{-}$ligands towards that of the $\mathrm{Cl}^{-}$ligand. This leveling of relative basicities of the halide ligands appears to be another factor which determines the ratios of Table 6. 
A third factor relevant to Table 6 is the increased ionic radii and polarisabilities of the donors. Table 5 shows that the $\mathrm{I}^{-}$ligand is the most polarisable of the halide ions. Other factors remaining equal, an increase in the polarisability of the donor would make the donor-acceptor interaction stronger. The dipole moments of $\mathrm{SO}_{2}$ and $\mathrm{SOCl}_{2}$ are 1.61 and $1.60 \mathrm{D}$ respectively. If polarisability was the only factor one would expect the iodide complex to be the most stable. This was not so, indicating that back-donation is a still more important factor in deciding the nature of association of the halide ligands with $\mathrm{SOCl}_{2}$. Sulphonyl chloride, $\mathrm{SO}_{2} \mathrm{Cl}_{2}$, is the strongest acceptor of this group of sulfur compounds; it has the highest dipole moment (1.86 $\mathrm{D})$. The $d$-orbitals of sulfur here are the most exposed for coordination than in the other acceptors. The order of stability of its halide ligand complexes is: $\mathrm{SO}_{2} \mathrm{Cl}_{2}-\mathrm{I}^{-}>\mathrm{SO}_{2} \mathrm{Cl}_{2}-\mathrm{Br}^{-}>\mathrm{SO}_{2} \mathrm{Cl}_{2}-\mathrm{Cl}^{-}$which is the reverse of $\mathrm{SO}_{2}-\mathrm{X}^{-}$and $\mathrm{SOCl}_{2}-\mathrm{X}^{-}$species (Table 4) suggesting that back-donation cannot be strong in the formation of $\mathrm{SO}_{2} \mathrm{Cl}_{2}-\mathrm{X}^{-}$complexes.

The increased acidity of $\mathrm{SO}_{2} \mathrm{Cl}_{2}$ seems now to be very important. In the presence of such a relatively strong Lewis acid the three Lewis bases appear to lose their identity and are of merely equal strength. Thus the leveling effect observed for $\mathrm{SOCl}_{2}$ is probably more strongly displayed. In protonic systems this leveling explains why benzoic acid and sulfuric acid are equally strong in liquid ammonia while water, alcohol, ketones.... etc are equally strong bases in pure sulfuric acid (Bell, 1965; Waddington, 1965).

It appears that increased polarisability towards $\mathrm{I}^{-}$, the increased polarity towards $\mathrm{SO}_{2} \mathrm{Cl}_{2}$ and the increased leveling effect can account for the order of stability constants observed for $\mathrm{SOCl}_{2}-\mathrm{X}^{-}$complex species. The effect of polarisability of the halide ligands on the order of stability of some metal complexes has been reported (Gould, 1960).

We may conclude that as the acceptor is changed from $\mathrm{SO}_{2}$ to $\mathrm{SO}_{2} \mathrm{Cl}_{2}$ the nature of association also changes. With $\mathrm{SO}_{2} d_{\Pi}-d_{\Pi}$ multiple bonding from back-donation makes its association with halide ligands quite strong but with $\mathrm{SO}_{2} \mathrm{Cl}_{2}$ the dipole-dipole interaction seems to be a weaker force of association, as shown from $\Delta \mathrm{H}_{\mathrm{f}}{ }^{\mathrm{o}}$ values in Table 3 and the $\mathrm{K}_{\mathrm{c}}$ values of Table 4.

\section{Solvent Effects on Stability of $\mathrm{SO}_{2}-\mathrm{X}^{-}, \mathrm{SOCl}_{2}-\mathrm{X}^{-}$and $\mathrm{SO}_{2} \mathrm{Cl}_{2}-\mathrm{X}^{-}$}

\subsection{Pure Solvents}

Solvent molecules are not impartial in chemical processes and the extent to which they participate sometimes overshadows that of the other species in the reaction media. This is because the solvent represents the environment in which a chemical reaction takes place and in most cases plays the role of a donor or acceptor. The role of environment and solvent effects on chemical reactions has been discussed by a number of workers (Bell, 1965; Waddington, 1965; Frost et al., 1961; Benson, 1960; Amis, 1965; Gutmann, 1967, 1971; Grunwald, 1949). The $\mathrm{K}_{\mathrm{c}}$ values for $\mathrm{SO}_{2}-\mathrm{X}^{-}, \mathrm{SOCl}_{2}-\mathrm{X}^{-}$and $\mathrm{SO}_{2} \mathrm{Cl}_{2}-\mathrm{X}^{-}$in $\mathrm{MeCN}$, dmso and water recorded in Table 7 illustrate the solvent effects.

Table 7. Stability Constants for $\mathrm{SO}_{2}-\mathrm{X}^{-}, \mathrm{SOCl}_{2}-\mathrm{X}^{-}$and $\mathrm{SO}_{2} \mathrm{Cl}_{2}-\mathrm{X}^{-}$in $\mathrm{MeCN}$, dmso and water at $298^{\circ} \mathrm{K}$. $(\mathrm{a}=\mathrm{MeCN}, \mathrm{b}=\mathrm{dmso}$, and $\mathrm{c}=$ water $)$

\begin{tabular}{|c|c|c|c|c|c|c|c|c|}
\hline \multirow{2}{*}{$\mathrm{X}^{-}$} & \multicolumn{2}{|c|}{$\mathrm{Cl}^{-}$} & \multicolumn{3}{c|}{$\mathrm{Br}^{-}$} & \multicolumn{3}{c|}{$\mathrm{I}^{-}$} \\
\cline { 2 - 10 } & $\mathrm{a}$ & $\mathrm{b}$ & $\mathrm{a}$ & $\mathrm{b}$ & $\mathrm{c}$ & $\mathrm{a}$ & $\mathrm{b}$ & $\mathrm{c}$ \\
\hline $\mathrm{SO}_{2}-\mathrm{X}^{-}$ & 372 & 26 & 160 & 21 & 0.22 & 38 & 12 & 0.36 \\
\hline $\mathrm{SOCl}_{2}-\mathrm{X}^{-}$ & 362 & 18 & 241 & 21 & & 150 & 35 & \\
\hline $\mathrm{SO}_{2} \mathrm{Cl}_{2}-\mathrm{X}^{-}$ & 10 & 36 & 41 & 14 & & 71 & 6 & \\
\hline
\end{tabular}




\section{WEAK COMPLEXES OF SULFUR COMPOUNDS}

Comparison of $\mathrm{K}_{\mathrm{c}}$ data is limited to the values in $\mathrm{MeCN}$ and dmso. With the exception of $\mathrm{SO}_{2} \mathrm{Cl}_{2}-\mathrm{X}^{-}$ species, the stability constants of different complexes decreased by a factor of nearly 20 in dmso as compared to MeCN which is shown from the data in Table 8.

Table 8. Comparison of Stability Constants in $\mathrm{MeCN}$ and dmso $\mathrm{K}_{\mathrm{c}}(\mathrm{MeCN}) / \mathrm{K}_{\mathrm{c}}(\mathrm{dmso})$ at $298^{\circ} \mathrm{K}$.

\begin{tabular}{|l|c|c|c|}
\hline $\mathrm{X}^{-}$ & $\mathrm{Cl}^{-}$ & $\mathrm{Br}^{-}$ & $\mathrm{I}^{-}$ \\
\hline $\mathrm{SO}_{2}-\mathrm{X}^{-}$ & 15 & 8 & 3 \\
\hline $\mathrm{SOCl}_{2}-\mathrm{X}^{-}$ & 20 & 11 & 4 \\
\hline $\mathrm{SO}_{2} \mathrm{Cl}_{2}-\mathrm{X}^{-}$ & 0.3 & 3 & 13 \\
\hline
\end{tabular}

The data in Tables 7 and 8 express significant changes in complex stabilities between MeCN and dmso, as the $\mathrm{K}_{\mathrm{c}}$ values are lower in dmso than in MeCN. There are at least two possible roles that can be played by dmso (or water) in affecting the stabilities of the complex species. It may solvate the halide ligands, which prevents them from interacting with the acceptors, i.e. sulfur compounds, or it may act as a competing acceptor, i.e. competes against $\mathrm{SO}_{2}, \mathrm{SOCl}_{2}$, and $\mathrm{SO}_{2} \mathrm{Cl}_{2}$ and thus makes a complex species with the ligands and perhaps it may play the two roles depending on the environmental conditions. Table 8 shows some horizontal and vertical trends.

The data in column (1) show maximum decrease in $\mathrm{K}_{\mathrm{c}}$ for $\mathrm{SO}_{2}-\mathrm{Cl}^{-}$and also for $\mathrm{SOCl}_{2}-\mathrm{Cl}^{-}$in dmso. This can be attributed to solvation of the $\mathrm{Cl}^{-}$ligand and possibly ion-dipole interaction in view of the high dipole moment of dmso (4.3D). In these species, stabilization results from back-donation (Mines et al., 1972; Chadwick, 1973) from sulfur $3 d$-orbitals to the donor ligand. Minimum effect is shown for $\mathrm{SO}_{2} \mathrm{Cl}_{2}-\mathrm{Cl}^{-}$ where $\mathrm{K}_{\mathrm{c}}(\mathrm{MeCN}) / \mathrm{K}_{\mathrm{c}}(\mathrm{dmso})$ equals 0.3 , which shows the importance of polarization and not back-donation in stabilizing $\mathrm{SO}_{2} \mathrm{Cl}_{2}-\mathrm{Cl}^{-}$species.

In column (2) ratios for $\mathrm{SO}_{2}-\mathrm{Br}^{-}$and $\mathrm{SOCl}_{2}-\mathrm{Br}^{-}$are nearly half those reported for the $\mathrm{Cl}^{-}$species, which is regarded as reflecting the lower tendency to solvation of the $\mathrm{Br}^{-}$ligand as compared to $\mathrm{Cl}^{-}$by dmso. In column (3) the ratios of $\mathrm{SO}_{2}-\mathrm{I}^{-}$and $\mathrm{SOCl}_{2}-\mathrm{I}^{-}$are nearly $1 / 4$ of the values for the $\mathrm{Cl}^{-}$species. This shows the lower tendency of $\mathrm{I}^{-}$ligands to solvate and this is not unexpected due to the larger ionic size of $\mathrm{I}^{-}$.

The horizontal trends in $\mathrm{SO}_{2}-\mathrm{X}^{-}$and $\mathrm{SOCl}_{2}-\mathrm{X}^{-}$appear to agree with the conclusion that solvation of the donor ligands by dmso is important in decreasing the stability constants compared with those in MeCN and that this lowering is maximal with $\mathrm{Cl}^{-}$ligands and minimal with $\mathrm{I}^{-}$ligands. The $\mathrm{K}_{\mathrm{c}}$ values in water appear to support this view.

For $\mathrm{SO}_{2} \mathrm{Cl}_{2}-\mathrm{X}^{-}$the horizontal tend is reversed compared to that shown by $\mathrm{SO}_{2}-\mathrm{X}^{-}$and $\mathrm{SOCl}_{2}-\mathrm{X}^{-}$. This supports the view that the nature of association in $\mathrm{SO}_{2} \mathrm{Cl}_{2}-\mathrm{X}^{-}$is different from that in $\mathrm{SO}_{2}-\mathrm{X}^{-}$and $\mathrm{SOCl}_{2}-\mathrm{X}^{-}$(Salama et al., 1971), the former being mainly ion-dipole interaction and the latter back-donation as mentioned earlier. The lowering in stability constants of $\mathrm{SO}_{2} \mathrm{Cl}_{2}-\mathrm{I}^{-}$and $\mathrm{SO}_{2} \mathrm{Cl}_{2}-\mathrm{Br}^{-}$is evidence that iondipole interaction is particularly strong between dmso and iodide ion (Salama et al., 1991), which is understandable in view of the higher dipole moment of dmso compared with $\mathrm{SO}_{2} \mathrm{Cl}_{2}$. The data in Table 8, column (3) for the iodide species show that ion-dipole interaction outweighs solvation, while those in column (1) show that solvation has the greater effect.

\subsection{Mixed Solvents: (MeCN-dmso)}

Few workers have reported on chemical processes in mixed solvents and also specified the role of solvent. The work to be outlined reports on the stability of $\mathrm{SO}_{2}-\mathrm{X}^{-}, \mathrm{SOCl}_{2}-\mathrm{X}^{-}$and $\mathrm{SO}_{2} \mathrm{Cl}_{2}-\mathrm{X}^{-}$in $\mathrm{MeCN}-$ dmso mixed solvent, and Table 9 (Salama et al., 1978) includes the $\mathrm{K}_{\mathrm{c}}$ data of these complex species in $\mathrm{MeCN}$, dmso and mixtures of the two solvents at $298^{\circ} \mathrm{K}$.

The data in columns 2 and 6 were quoted from Table 2. One feature appears throughout Table 9. The stability constants of all complex species, at $298^{\circ} \mathrm{K}$, vary with solvent composition. In order to rationalize 


\section{SALAMA and WASIF}

the $\mathrm{K}_{\mathrm{c}}$ values we shall discuss the horizontal and vertical trends in Table 9.

Table 9. Stability Constants for $\mathrm{SO}_{2}-\mathrm{X}^{-}, \mathrm{SOCl}_{2}-\mathrm{X}^{-}$, and $\mathrm{SO}_{2} \mathrm{Cl}_{2}-\mathrm{X}^{-}$in $\mathrm{MeCN}$, dmso, and their mixtures at $298^{\circ} \mathrm{K}$

\begin{tabular}{|l|c|c|c|c|c|}
\hline \multicolumn{1}{|c|}{ Complex } & dmso & \multicolumn{3}{c|}{ MeCN+dmso } & MeCN \\
\hline & & $\mathbf{1 : 3}$ & $\mathbf{1 : 1}$ & $\mathbf{3 : 1}$ & \\
\hline $\mathrm{SO}_{2}-\mathrm{I}^{-}$ & 12.1 & 14.1 & 24.7 & 36.7 & 37.9 \\
\hline $\mathrm{SO}_{2}-\mathrm{Br}^{-}$ & 21.0 & 14.5 & 24.1 & 40.1 & 40.1 \\
\hline $\mathrm{SO}_{2}-\mathrm{Cl}^{-}$ & 26.0 & 35.5 & 50.0 & 52.4 & 372.0 \\
\hline $\mathrm{SOCl}_{2}-\mathrm{I}^{-}$ & 35.0 & 40.2 & 58.9 & 223.5 & 150.0 \\
\hline $\mathrm{SOCl}_{2}-\mathrm{Br}^{-}$ & 21.0 & 22.9 & 34.2 & 71.7 & 241.0 \\
\hline $\mathrm{SOCl}_{2}-\mathrm{Cl}^{-}$ & 18.0 & 66.7 & 73.8 & 113.0 & 362.0 \\
\hline $\mathrm{SO}_{2} \mathrm{Cl}_{2}-\mathrm{I}^{-}$ & 6.0 & 30.1 & 50.1 & 142.2 & 76.0 \\
\hline $\mathrm{SO}_{2} \mathrm{Cl}_{2}-\mathrm{Br}^{-}$ & 14.0 & 15.5 & 24.6 & 36.2 & 41.0 \\
\hline
\end{tabular}

\subsection{The $\mathrm{SO}_{2}-\mathrm{X}^{-}$Species}

The $\mathrm{K}_{\mathrm{c}}$ values of $\mathrm{SO}_{2}-\mathrm{I}^{-}$change gradually between the limits set for $\mathrm{MeCN}$ and dmso as the solvent composition changes. In MeCN-dmso solvent $(3: 1)$ the $\mathrm{K}_{\mathrm{c}}$ value is reduced by $2.7 \%$ compared with that in $25 \%$ dmso solvent. For $\mathrm{SO}_{2}-\mathrm{Br}^{-}$and $\mathrm{SO}_{2}-\mathrm{Cl}^{-}$the $\mathrm{K}_{\mathrm{c}}$ values are reduced in the same solvent by $75 \%$ and $85 \%$ respectively. (The $\mathrm{K}_{\mathrm{c}}$ value in $\mathrm{MeCN}$ is taken as a reference in each case). Solvation of $\mathrm{Br}^{-}$and $\mathrm{Cl}^{-}$ ligands by dmso is clearly greater than that for the $\mathrm{I}^{-}$ligand. A similar conclusion was reached when $\mathrm{K}_{\mathrm{c}}$ for the same species were determined in MeCN and dmso (Salama et al., 1975). To correlate the variations in $\mathrm{K}_{\mathrm{c}}$ values with solvent composition it should be remembered that the molecules of different solvents can act as donors and/or acceptors. Even if both solvent molecules have donor or acceptor character a slight difference in the donor or acceptor properties between different solvent molecules will invite donoracceptor interaction between them. The nature of such interactions in non-protic solvent mixtures such as MeCN-dmso has not been studied before (Waddington, 1965).

Over a wide range of molecular ratios of $\mathrm{MeCN}$ and dmso one expects such interactions to exhibit different patterns which depend on the structural and geometrical characters of the molecules. We shall call this solvent-solvent interaction and may define it in terms of donor-acceptor interaction or perhaps association which vary with solvent composition.

Such solvent-solvent interactions may occur at the expense of other interactions in solution. For example in MeCN-dmso containing $\mathrm{SO}_{2}$ molecules and $\mathrm{Cl}^{-}$ligands and $\mathrm{SO}_{2}-\mathrm{Cl}^{-}$complex species the following interactions are likely to occur (a) $\mathrm{Cl}^{-}$-dmso, (b) $\mathrm{Cl}^{-}-\mathrm{MeCN}$, (c) $\mathrm{SO}_{2}$-dmso, (d) $\mathrm{SO}_{2}-\mathrm{MeCN}$ and (e) MeCN-dmso. The stability constant of the $\mathrm{SO}_{2}-\mathrm{Cl}^{-}$species is determined by the relative magnitudes of such interactions, a strong $\mathrm{Cl}^{-}$-solvent interaction (solvation) would reduce the stability of $\mathrm{SO}_{2}-\mathrm{Cl}^{-}$species, since this steric factor may prevent, to some extent, $\mathrm{SO}_{2}$ and $\mathrm{Cl}^{-}$from approaching each other for coordination. On the other hand a strong MeCN-dmso interaction would allow more $\mathrm{SO}_{2}$ to coordinate with $\mathrm{Cl}^{-}$ligands and $\mathrm{K}_{\mathrm{c}}$ values become greater than the limits set for each solvent.

The data for $\mathrm{SO}_{2}-\mathrm{X}^{-}$show that $\mathrm{MeCN}$-dmso interaction accounts partly for the change in $\mathrm{K}_{\mathrm{c}}$ with solvent changes. Ligand solvation is also important in determining $\mathrm{K}_{\mathrm{c}}$ values. The $\mathrm{K}_{\mathrm{c}}$ data show that while the $\mathrm{I}^{-}$-solvent interaction is relatively weak and reduces $\mathrm{K}_{\mathrm{c}}$ by $2.7 \%$ (in $25 \%$ dmso relative to its value in $\mathrm{MeCN}$ ) those of $\mathrm{Cl}^{-}$-solvent interactions and $\mathrm{Br}^{-}$-solvent interactions are much stronger and reduce $\mathrm{K}_{\mathrm{c}}$ by $85 \%$ and $75 \%$ for $\mathrm{SO}_{2}-\mathrm{Cl}^{--}$and $\mathrm{SO}_{2}-\mathrm{Br}^{-}$respectively.

\subsection{The $\mathrm{SOCl}_{2}-\mathrm{X}^{-}$and $\mathrm{SO}_{2} \mathrm{Cl}_{2}-\mathrm{X}^{-}$Series}

The $\mathrm{K}_{\mathrm{c}}$ values for $\mathrm{SOCl}_{2}-\mathrm{Cl}^{-}$and $\mathrm{SOCl}_{2}-\mathrm{Br}^{-}$fall between the limits set for $\mathrm{MeCN}$ and dmso but that for $\mathrm{SOCl}_{2} \mathrm{I}^{-}$species exceeds the upper limit in $\mathrm{MeCN}$ by $30 \%$ (in $25 \%$ dmso solvent). A change in solvent 


\section{WEAK COMPLEXES OF SULFUR COMPOUNDS}

composition from 50 to $25 \%$ dmso is coupled with a sudden change in $\mathrm{K}_{\mathrm{c}}$ for $\mathrm{SOCl}_{2}-\mathrm{I}^{-}$. It appears that over this critical range of solvent composition the solvent-solvent interaction reaches its maximum. The nature of this interaction is not yet clear but is detectable from vapor pressure measurements (Salama et al., 1985). Such interactions have freed sufficient $\mathrm{I}^{-}$ligands and $\mathrm{SOCl}_{2}$ molecules for coordination which makes $\mathrm{K}_{\mathrm{c}}$ $30 \%$ greater than the value in $\mathrm{MeCN}$. With $\mathrm{SOCl}_{2}-\mathrm{Cl}^{-}$and $\mathrm{SOCl}_{2} \mathrm{Br}^{-}$(in $25 \%$ dmso solvent) the $\mathrm{K}_{\mathrm{c}}$ values are reduced by $69 \%$ and $71 \%$ from the value in $\mathrm{MeCN}$. Thus, despite strong solvent-solvent interaction the $\mathrm{Br}^{-}$-solvent and $\mathrm{Cl}^{-}$-solvent interactions have outweighed solvent-solvent interactions. A similar argument applies to $\mathrm{SO}_{2} \mathrm{Cl}_{2}-\mathrm{I}^{-}$and $\mathrm{SO}_{2} \mathrm{Cl}_{2}-\mathrm{Br}^{-}$where $\mathrm{K}_{\mathrm{c}}$ increases by $61 \%$ for the iodide species and decreases by $15 \%$ for the bromide species.

\subsection{Vertical Correlations in Table 9}

\subsubsection{The Iodide Complex Series}

Although $\mathrm{K}_{\mathrm{c}}$ values for $\mathrm{SOCl}_{2}-\mathrm{I}^{-}$and for $\mathrm{SO}_{2} \mathrm{Cl}_{2}-\mathrm{I}^{-}$in $25 \%$ dmso are $30 \%$ and $64 \%$ greater than the value in $\mathrm{MeCN}$ we find that $\mathrm{K}_{\mathrm{c}}$ for $\mathrm{SO}_{2} \mathrm{I}^{-}$is $2.7 \%$ less than its value in $\mathrm{MeCN}$. Such differences in behavior are probably due to differences in the manner in which the $\mathrm{I}^{-}$ligand is coordinated to the three acceptors. The $\mathrm{I}^{-}$ligand is polarisable with diffuse $d$-orbitals suitable for ion-dipole interaction. The dipole moment of the three acceptors are in the order $\mathrm{SO}_{2}$ (1.61D) $\mathrm{SOCl}_{2}$ (1.60D) and $\mathrm{SO}_{2} \mathrm{Cl}_{2}$ (1.86D). In 25\% dmso solvent strong solvent-solvent interaction favors $\mathrm{SO}_{2} \mathrm{Cl}_{2}-\mathrm{I}^{-}$coordination so that the $\mathrm{K}_{\mathrm{c}}$ value exceeds that in $\mathrm{MeCN}$ by $64 \%$. The acceptor character of $\mathrm{SOCl}_{2}$ is enhanced by the replacement of one $\mathrm{O}$ atom in $\mathrm{SO}_{2}$ by $2 \mathrm{Cl}$ atoms and coordination by ion-dipole interaction is relatively stronger with $\mathrm{I}^{-}$than with $\mathrm{SO}_{2}$. Solvent-solvent interaction helps coordination of $\mathrm{SOCl}_{2}$ to $\mathrm{I}^{-}$and results in a $\mathrm{K}_{\mathrm{c}}$ value which exceeds that in $\mathrm{MeCN}$ by $30 \%$. For $\mathrm{SO}_{2}-\mathrm{I}^{-}$the ion-dipole interaction is probably so weak that is nearly balanced by solventsolvent interaction and $\mathrm{K}_{\mathrm{c}}$ is slightly reduced by $2.7 \%$.

\subsubsection{The Bromide and Chloride Complex Series}

The decrease in the $\mathrm{K}_{\mathrm{c}}$ values for $\mathrm{SO}_{2}-\mathrm{Br}^{-}, \mathrm{SOCl}_{2}-\mathrm{Br}^{-}$and $\mathrm{SO}_{2} \mathrm{Cl}_{2}-\mathrm{Br}^{-}$(in $25 \%$ dmso solvent) by 76 , 71 and $15 \%$ respectively resulted from $\mathrm{Br}^{-}$- solvent interaction. The difference arises from differences in the modes of coordination of the three acceptors. For $\mathrm{SO}_{2}$ and $\mathrm{SOCl}_{2}$ back-donation is the principal mechanism by which coordination takes place to $\mathrm{S}(\mathrm{IV})$. For $\mathrm{SO}_{2}-\mathrm{Br}^{-}$and $\mathrm{SOCl}_{2}-\mathrm{Br}^{-}$solvent-solvent interaction is outweighed by $\mathrm{Br}^{-}$- solvent interaction and $\mathrm{K}_{\mathrm{c}}$ is reduced accordingly. For $\mathrm{SO}_{2} \mathrm{Cl}_{2}-\mathrm{Br}^{-}$coordination occurs

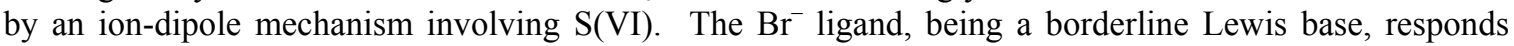
favorably to this mechanism and by its solvation by dmso slightly outweighs solvent-solvent interaction and $\mathrm{K}_{\mathrm{c}}$ is reduced to a smaller extent than in the other bromides.

For $\mathrm{SO}_{2}-\mathrm{Cl}^{-}$and $\mathrm{SOCl}_{2}-\mathrm{Cl}^{-}$back-donation is the principal mechanism for coordination. In both species the $\mathrm{Cl}^{-}$-solvent interaction outweighs solvent-solvent interaction and $\mathrm{K}_{\mathrm{c}}$ values are reduced by 85 and $69 \%$ respectively. This differing effect on $\mathrm{K}_{\mathrm{c}}$ might be due to selective solvation in the presence of different acceptors which we may describe as chemical environmental factors.

\subsection{Evidence for Solvent-Solvent Interactions}

\subsubsection{Spectroscopic}

Using the IR (infra red) techniques, it is found that the $\mathrm{S}=\mathrm{O}$ vibration band of dmso appears at 1080 $\mathrm{cm}^{-1}$ and on addition of MeCN the band is shifted to $1070 \mathrm{~cm}^{-1}$. The $\mathrm{C} \equiv \mathrm{N}$ vibration band of MeCN appears at $2250 \mathrm{~cm}^{-1}$ and adding dmso at $\mathrm{x}_{1}=0.5\left(\mathrm{x}_{1}=\right.$ mol fraction) the band is shifted to $2240 \mathrm{~cm}^{-1}$ (Salama et al., 1985).

Using Raman spectra it is found that the $\mathrm{S}=\mathrm{O}$ vibration band appears at $1044 \mathrm{~cm}^{-1}$ and on adding $\mathrm{MeCN}$ a peak appears at $1062 \mathrm{~cm}^{-1}$ while that at $1044 \mathrm{~cm}^{-1}$ disappears. For $\mathrm{MeCN}$ the $\mathrm{C} \equiv \mathrm{N}$ vibration band appears at $2255 \mathrm{~cm}^{-1}$ and on addition of dmso the band disappears gradually. The observed vibrational shifts 


\section{SALAMA and WASIF}

may be taken as evidence for solvent-solvent interaction through adduct formation of the type represented by Figure 3 .

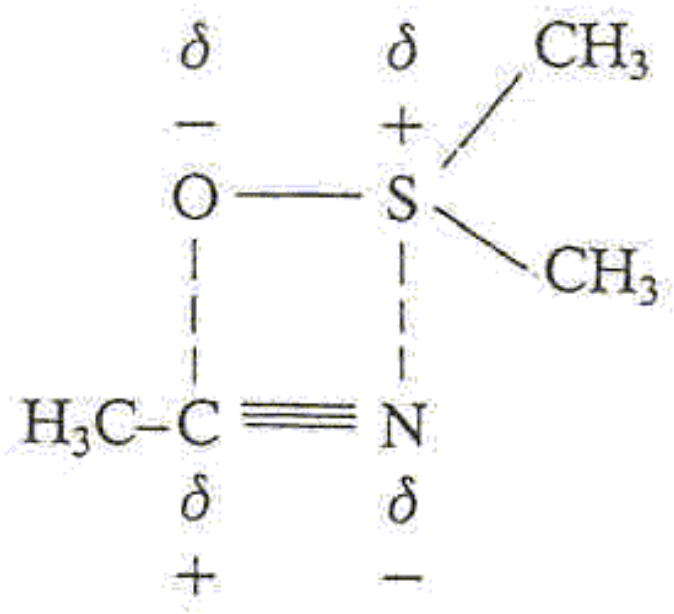

Figure 3. MeCN-dmso Adduct

\subsubsection{Vapor-Pressure, Viscosity, and Excess Functions from Refractive Index, Dielectric Constant} and Volume

Further confirmation for solvent-solvent interaction was obtained from measurements of vapor pressure and viscosity of MeCN-dmso mixtures. Table 10 includes vapor pressure, viscosity, $\Delta \mathrm{H}_{\text {vap }}, \Delta \mathrm{S}_{\text {vap }}$, and $\Delta \mathrm{H}_{\text {vis }}$, of the mixtures over the whole composition range.

Table 10. Vapour pressures and viscosities of MeCN-dmso mixtures

10(a). Vapour Pressure Data

\begin{tabular}{|c|c|c|c|c|c|c|c|}
\hline $25 \% \mathrm{MeCN}$ & $\mathrm{t} /{ }^{\circ} \mathrm{C}$ & 61.6 & 69.0 & 75.6 & 80.7 & 85.7 & \\
& $\mathrm{p} / \mathrm{mmHg}$ & 58.0 & 72.0 & 84.0 & 99.0 & 115.5 & \\
\hline $50 \% \mathrm{MeCN}$ & $\mathrm{t} /{ }^{\circ} \mathrm{C}$ & 29.0 & 34.5 & 39.9 & 45.0 & 49.0 & 54.0 \\
& $\mathrm{p} / \mathrm{mmHg}$ & 69.7 & 76.1 & 95.6 & 115.6 & 136.3 & 163.6 \\
\hline $75 \% \mathrm{MeCN}$ & $\mathrm{t} /{ }^{\circ} \mathrm{C}$ & 28.4 & 33.1 & 38.5 & 43.7 & 49.4 & \\
& $\mathrm{p} / \mathrm{mmHg}$ & 78.9 & 95.4 & 119.4 & 147.9 & 186.9 & \\
\hline $80 \% \mathrm{MeCN}$ & $\mathrm{t} /{ }^{\circ} \mathrm{C}$ & 28.4 & 33.4 & 38.9 & 45.1 & 51.6 & \\
& $\mathrm{p} / \mathrm{mmHg}$ & 84.7 & 106.5 & 134.0 & 160.0 & 213.0 & \\
\hline
\end{tabular}

10(b). Viscosity Data

\begin{tabular}{|c|c|c|c|}
\hline $\mathbf{t} /{ }^{\circ} \mathbf{C}$ & $\mathbf{2 5 . 0}$ & $\mathbf{3 0 . 0}$ & $\mathbf{3 5 . 0}$ \\
\hline $\mathrm{MeCN}$ & 3.55 & 3.38 & $3.30 \times 10^{-4} \mathrm{Pas}$ \\
\hline $75 \% \mathrm{MeCN}$ & 5.17 & 4.89 & 4.73 \\
\hline $50 \% \mathrm{MeCN}$ & 7.44 & 7.04 & 6.68 \\
\hline $25 \% \mathrm{MeCN}$ & 11.71 & 10.85 & 10.16 \\
\hline $\mathrm{dmso}$ & 19.57 & 17.88 & 16.40 \\
\hline
\end{tabular}




\section{WEAK COMPLEXES OF SULFUR COMPOUNDS}

10(c). Thermodynamic Data for Vaporization and Viscosity

\begin{tabular}{|c|c|c|c|c|c|c|}
\hline Solvent & $\mathrm{MeCN}$ & $\begin{array}{c}80 \% \\
\mathrm{MeCN}\end{array}$ & $\begin{array}{c}75 \% \\
\mathrm{MeCN}\end{array}$ & $\begin{array}{c}50 \% \\
\mathrm{MeCN}\end{array}$ & $\begin{array}{c}25 \% \\
\mathrm{MeCN}\end{array}$ & dmso \\
\hline$\Delta \mathrm{H}_{\text {vap }} \mathrm{kJ} / \mathrm{mol}$ & 33.2 & 31.8 & 33.3 & 29.1 & 28.2 & 52.9 \\
\hline$\Delta \mathrm{S}_{\text {vap }} \mathrm{J} / \mathrm{K} / \mathrm{mol}$ & 96.0 & 87.1 & 91.4 & 72.9 & 62.7 & 95.8 \\
\hline$\Delta \mathrm{H}_{\text {vis }} \mathrm{kJ} / \mathrm{mol}$ & 5.48 & 6.57 & 7.74 & 8.24 & 10.6 & 13.3 \\
\hline
\end{tabular}

Figure 4 shows a plot of $\Delta \mathrm{H}_{\mathrm{vap}}$ and $\Delta \mathrm{H}_{\mathrm{vis}}$ against solvent composition. The plots are not linear and deviate over the composition range 50-70\% (maximum deviation which may be taken to indicate solventsolvent interaction). The $\Delta \mathrm{S}_{\text {vap }}$ data show a minimum value at $75 \%$ dmso suggesting maximum order for the system at this composition with probable formation of MeCN-dmso adduct.

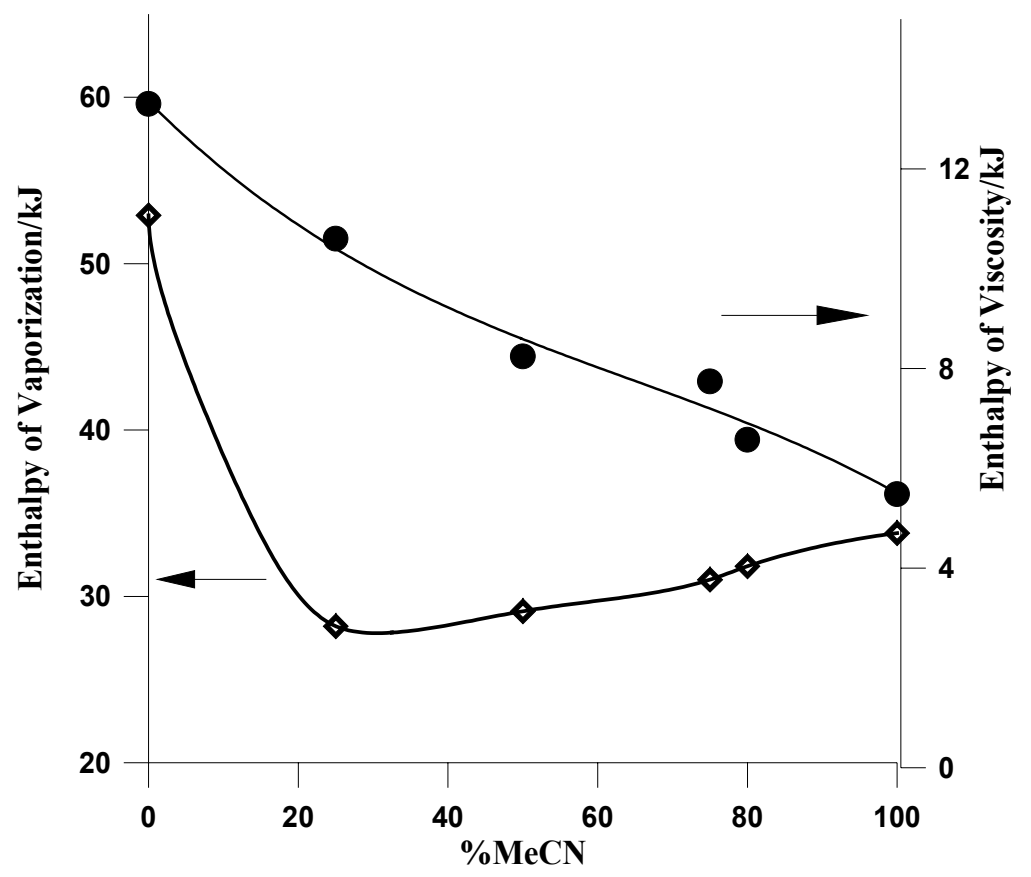

Figure 4. Plot of Enthalpy of Vaporization/kJ (•) and Enthalpy of Viscosity $/ \mathrm{kJ}(\bullet)$ against $\% \mathrm{MeCN}$

The excess functions from refractive index $\mathrm{n}^{\mathrm{E}}$, dielectric constant $\varepsilon^{\mathrm{E}}$ and densities $\mathrm{V}^{\mathrm{E}}$ of MeCN-dmso mixtures are given in Table 11 (Salama et al., 1985). The data in Table 11 show that the magnitude of any excess function reaches a maximum at approximately 1:1 composition. This is again taken to indicate solvent-solvent interaction.

Table 11. Excess Functions of MeCN-dmso mixtures at $298^{\circ} \mathrm{K}$

11(a). Refractive Index $\left(\mathrm{n}^{\mathrm{E}}\right)$

\begin{tabular}{|l|l|l|l|l|l|l|}
\hline $\mathrm{X}_{1}$ & 0.1319 & 0.2676 & 0.4258 & 0.6899 & 0.7836 & 0.8697 \\
\hline $\mathrm{n}^{\mathrm{E}}$ & 0.0030 & 0.0076 & 0.0087 & 0.0102 & 0.0065 & 0.0039 \\
\hline
\end{tabular}


11(b). Dielectric Constant $\left(\varepsilon^{\mathrm{E}}\right)$

\begin{tabular}{|c|c|c|c|c|c|c|c|}
\hline $\mathrm{x}_{1}$ & 0.1319 & 0.2676 & 0.4258 & 0.6009 & 0.6899 & 0.7836 & 0.8697 \\
\hline$\varepsilon^{\mathrm{E}}$ & 0.5710 & 0.9540 & 1.3180 & 1.4910 & 1.3680 & 1.1960 & 0.8630 \\
\hline
\end{tabular}

$11(\mathrm{c})$. Volume $\left(\mathrm{V}^{\mathrm{E}}\right) .\left(\mathrm{x}_{1}=\right.$ mole fraction of dmso)

\begin{tabular}{|c|c|c|c|c|c|c|c|}
\hline $\mathrm{x}_{1}$ & 0.1006 & 0.3066 & 0.6037 & 0.7061 & 0.8083 & 0.8999 & 0.9455 \\
\hline $\mathrm{V}^{\mathrm{E}}$ & -0.1300 & -0.2523 & -0.2519 & -0.1773 & -0.1275 & -0.0876 & -0.0486 \\
\hline
\end{tabular}

\subsection{A Thermodynamic View of Solvent Effects on The Stability of $\mathrm{SO}_{2}-\mathrm{X}^{-}, \mathrm{SOCl}_{2}-\mathrm{X}^{-}$and $\mathrm{SO}_{2} \mathrm{Cl}_{2}-\mathrm{X}^{-}$}

\subsubsection{The Significance of $\Delta \mathbf{G}_{\mathbf{f}}^{0}$ of Complexes in Relation to Solute-Solvent Interactions:}

Table 12 includes the standard free energies of formation $\Delta \mathrm{G}_{\mathrm{f}}{ }^{0}$ of $\mathrm{SO}_{2}-\mathrm{X}^{-}$and $\mathrm{SOCl}_{2}-\mathrm{X}^{-}$in $\mathrm{MeCN}$, dmso, and their mixtures.

Table 12. $-\Delta \mathrm{G}_{\mathrm{f}}{ }^{\mathrm{o}}(\mathrm{kJ} / \mathrm{mol})$ of complex species in different solvents at $298^{\circ} \mathrm{K}$

\begin{tabular}{|c|c|c|c|c|c|}
\hline & & \multicolumn{3}{|c|}{ dmso: MeCN } & \\
\cline { 3 - 5 } & dmso & $3: 1$ & $1: 1$ & $1: 3$ & \multirow{2}{*}{$\mathrm{MeCN}$} \\
\cline { 3 - 5 } & & & & & \\
\hline $\mathrm{SO}_{2}-\mathrm{I}^{-}$ & 6.19 & 6.57 & 8.03 & 9.00 & 9.08 \\
\hline $\mathrm{SO}_{2}-\mathrm{Br}^{-}$ & 7.61 & 6.74 & 7.91 & 9.20 & 8.49 \\
\hline $\mathrm{SO}_{2}-\mathrm{Cl}^{-}$ & 8.12 & 8.95 & 9.75 & 10.9 & 10.6 \\
\hline $\mathrm{SOCl}_{2}-\mathrm{I}^{-}$ & 8.87 & 9.20 & 10.2 & 13.5 & 12.5 \\
\hline $\mathrm{SOCl}_{2}-\mathrm{Br}^{-}$ & 7.61 & 7.82 & 8.79 & 10.7 & 13.7 \\
\hline $\mathrm{SOCl}_{2}-\mathrm{Cl}^{-}$ & 7.20 & 10.5 & 10.7 & 11.8 & 14.6 \\
\hline
\end{tabular}

The data in Table 12 show that for every complex species there are several free energy minima, each corresponding to a different solvent composition. This situation is only possible if a change in the solvent composition affects continuously the coordinating ability of the halide ligand $\left(\mathrm{X}^{-}\right)$with the sulfur acceptor $\left(\mathrm{SO}_{2}\right.$ or $\left.\mathrm{SOCl}_{2}\right)$ and partially hinders them from complex formation and which was described as solvation. Preliminary studies (Wasif, unpublished work) show that halide ion solvation in $\mathrm{MeCN}$ and dmso falls in the order $\mathrm{Cl}^{-}>\mathrm{Br}>\mathrm{I}^{-}$, which agrees with their ionic radii and charge densities.

Solvation of the sulfur acceptors was studied in the present work by UV spectroscopy. Figure 5 shows the absorbance of $\mathrm{SOBr}_{2}$ in (a) $\mathrm{MeCN}$, (b) dmso and (c) 1:1 mixed solvent of MeCN-dmso. It shows three distinct species which obey Beer's law. The intermediate absorbance of the 1:1 mixed solvent shows that $\mathrm{SOBr}_{2}$ forms an absorbing species of intermediate character between the species in dmso and $\mathrm{MeCN}$. There are two possibilities in which this could happen: (1) The formation of a constant ratio of the adduct species $\mathrm{SOBr}_{2}-\mathrm{MeCN}$ and $\mathrm{SOBr}_{2}-\mathrm{dmso}$, (2) that $\mathrm{SOBr}_{2}$ makes a species with a mixed solvent adduct e.g. $\left(\mathrm{SOBr}_{2}-\mathrm{MeCN}\right.$ :dmso). Using $\mathrm{CCl}_{4}$ as solvent the species $\mathrm{SOBr}_{2}-\mathrm{MeCN}$ and $\mathrm{SOBr}_{2}$-dmso were detectable and their stability constants are given in Table 13.

The data in Table 13 show that solvents MeCN and dmso play a competing role against halide ligands in their coordination with the sulfur acceptors. The data also show dmso to have a greater destabilizing role 


\section{WEAK COMPLEXES OF SULFUR COMPOUNDS}

Table 13. Stability Constants of Adducts of MeCN and dmso with Sulfur Compounds at $298^{\circ} \mathrm{K}$.

\begin{tabular}{|l|l|l|l|l|}
\hline $\mathrm{A}$ & $\mathrm{SO}_{2}$ & $\mathrm{SOCl}_{2}$ & $\mathrm{SOBr}_{2}$ & $\mathrm{SO}_{2} \mathrm{Cl}_{2}$ \\
\hline dmso-A & 2.82 & 6.86 & 3.73 & 17.79 \\
\hline MeCN-A & 0.34 & 0.07 & 0.11 & 0.68 \\
\hline
\end{tabular}

for the complex species than does $\mathrm{MeCN}$, by its strong ability to solvate the halide ligands and the sulfur compounds.

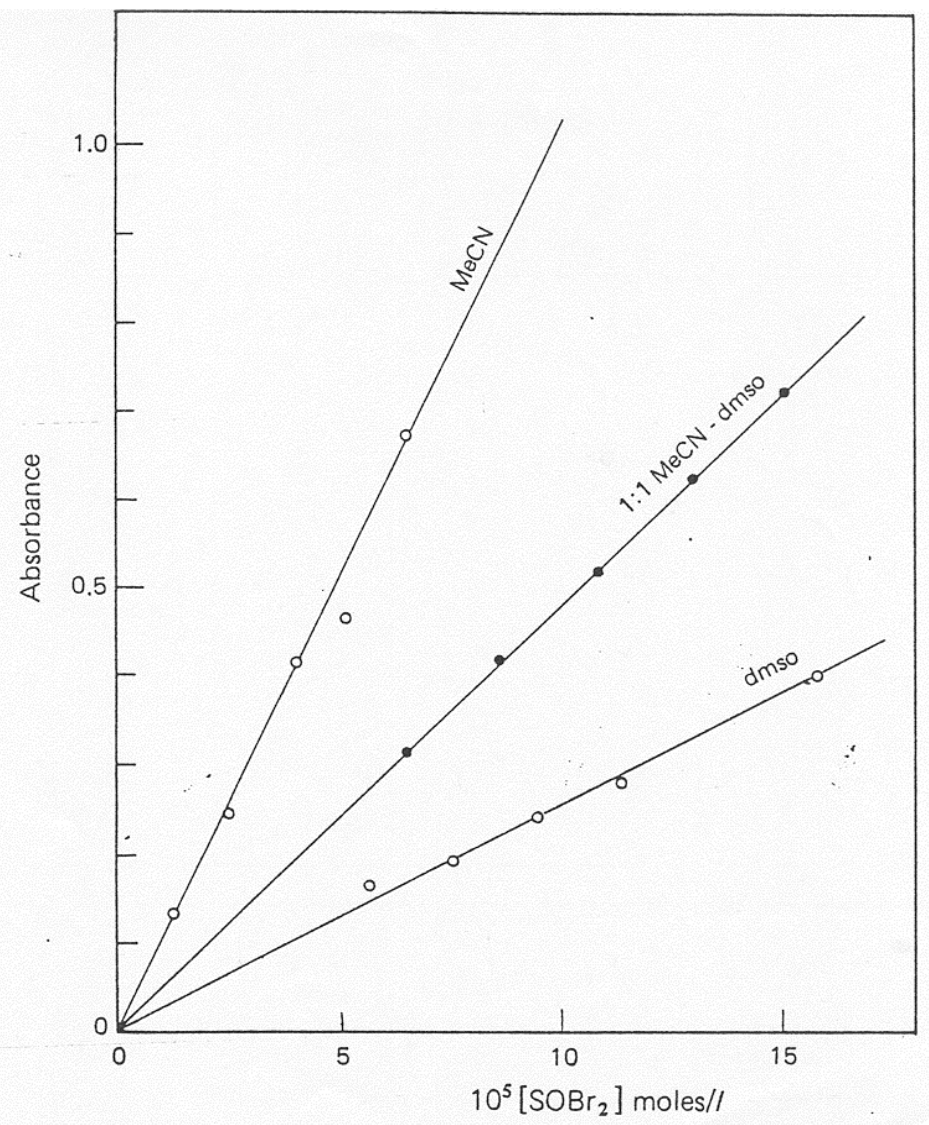

Figure 5. Dependence of Absorbance of $\mathrm{SOBr}_{2}$ On Solvent Mole Fraction

\subsubsection{The Dependence of $\Delta \mathrm{H}_{\mathrm{f}}{ }^{0}$ and $\Delta \mathrm{S}_{\mathrm{f}}{ }^{0}$ of Complex Species on Solvent Composition:}

A second thermodynamic aspect would be to consider the significance of $\Delta \mathrm{H}_{\mathrm{f}}{ }^{\circ}$ and $\Delta \mathrm{S}_{\mathrm{f}}{ }^{0}$ for complex species in mixed solvents. Table 14 includes the standard thermodynamic constants for the formation of the complex species $\mathrm{SOBr}_{2}-\mathrm{Cl}^{-}$and $\mathrm{SOBr}_{2}-\mathrm{Br}^{-}$.

Table 14 shows that the standard enthalpy of formation varies as the solvent composition changes from $\mathrm{MeCN}$ to dmso. For $\mathrm{SOBr}_{2}-\mathrm{Br}^{-} \Delta \mathrm{H}_{\mathrm{f}}{ }^{\mathrm{D}}$ is nearly 10 times greater in $\mathrm{MeCN}$ than in dmso but for $\mathrm{SOBr}_{2}-$ $\mathrm{Cl}^{-}$it is nearly 5 times greater than the value in dmso. Such differences in $\Delta \mathrm{H}_{\mathrm{f}}{ }^{\mathrm{o}}$ values suggest that the 


\section{SALAMA and WASIF}

measured enthalpy of formation is a rather complex function. It does not probably represent the heat of formation of the complex species but other heat terms are possibly embodied in this term such as heats of solvation of the halide ligands and sulfur compounds in $\mathrm{MeCN}$ and dmso. If $\Delta \mathrm{H}_{\mathrm{f}}{ }^{\mathrm{O}}$ be taken as a rough measure for the complex stability, then data in Table 14 would show that the complex species $\mathrm{SOBr}_{2}-\mathrm{X}^{-}\left(\mathrm{X}^{-}\right.$ $=\mathrm{Cl}, \mathrm{Br}$ ) are more stable in $\mathrm{MeCN}$ than they are in dmso. A thorough discussion of the significance of $\Delta \mathrm{H}_{\mathrm{f}}{ }^{\mathrm{O}}$ data requires a knowledge of the heats of solvation of the different species in both solvents which are not at present available. This situation permits a qualitative discussion of $\Delta \mathrm{H}_{\mathrm{f}}{ }^{\circ}$ data. Since solute-solvent interactions are a dynamically changing process we may expect the magnitude of $\Delta H_{\text {solvation values to change }}$ over the solvent concentration range, which is confirmed directly from Table 14. With this situation in mixed polar solvents a discussion of $\Delta \mathrm{S}_{\mathrm{f}}{ }^{\mathrm{o}}$ values would be difficult to interpret.

Table 14. Thermodynamic constants of $\mathrm{SOBr}_{2}-\mathrm{Cl}^{-}$and $\mathrm{SOBr}_{2}-\mathrm{Br}^{-}$in $\mathrm{MeCN}$, dmso and their Mixtures at $298^{\circ} \mathrm{K}$.

\begin{tabular}{|c|c|c|c|c|c|}
\hline & \multirow[b]{2}{*}{ dmso } & \multicolumn{3}{|c|}{ dmso: $\mathrm{MeCN}$} & \multirow[t]{2}{*}{$\mathrm{MeCN}$} \\
\hline & & 3:1 & $1: 1$ & $1: 3$ & \\
\hline $\mathrm{SOBr}_{2}-\mathrm{Br}^{-}$ & & & & & \\
\hline $\mathrm{K} \mathrm{dm}^{3} / \mathrm{mol}$ & 12 & 19 & & 32 & 203 \\
\hline$-\Delta \mathrm{G}_{\mathrm{f}}^{\mathrm{o}} \mathrm{kJ} / \mathrm{mol}$ & 5.86 & 7.36 & 8.03 & 8.66 & 13.3 \\
\hline$-\Delta \mathrm{H}_{\mathrm{f}}^{\mathrm{o}} \mathrm{kJ} / \mathrm{mol}$ & 1.88 & 4.60 & 4.60 & 20.1 & 19.2 \\
\hline$\Delta \mathrm{S}_{\mathrm{f}}{ }^{0} \mathrm{~J} / \mathrm{K} / \mathrm{mol}$ & 13.4 & 9.20 & 11.3 & -38.5 & -20.1 \\
\hline $\mathrm{SOBr}_{2}-\mathrm{Cl}^{-}$ & & & & & \\
\hline $\mathrm{K}_{\mathrm{c}} \mathrm{dm}^{3} \cdot \mathrm{mol}^{-1}$ & 19 & 36 & 40 & 79 & 100 \\
\hline$-\Delta \mathrm{G}_{\mathrm{f}}^{\mathrm{o}} \mathrm{kJ} / \mathrm{mol}$ & 7.36 & 8.95 & 9.20 & 10.9 & 11.5 \\
\hline$-\Delta \mathrm{H}_{\mathrm{f}}^{\mathrm{o}} \mathrm{kJ} / \mathrm{mol}$ & 1.88 & 10.0 & 9.62 & 16.3 & 10.0 \\
\hline$\Delta \mathrm{S}_{\mathrm{f}}{ }^{0} \mathrm{~J} / \mathrm{K} / \mathrm{mol}$ & 18.4 & -2.93 & -1.26 & -18.0 & 5.02 \\
\hline
\end{tabular}

\section{Ligand Replacement Reactions}

The coordination of different ligands $\left(\mathrm{Cl}^{-}, \mathrm{Br}^{-} \mathrm{I}^{-}\right.$or $\left.\mathrm{SCN}^{-}\right)$with the same sulfur acceptors giving varying stability constants suggested that they are differently coordinated and could accordingly be able to replace each other with the same acceptor. Equation (5) shows a general replacement reaction between $\mathrm{SO}_{2}$ $\mathrm{I}^{-}$and $\mathrm{X}^{-}\left(\mathrm{X}^{-}=\mathrm{Cl}, \mathrm{Br}, \mathrm{SCN}\right)$ and Figure 6 illustrates a spectrophotometric scan when $\mathrm{SCN}^{-}$is added to $\mathrm{SO}_{2^{-}}$ $\mathrm{I}^{-}$in MeCN (Salama et al., 1978).

$$
\mathrm{SO}_{2} \mathrm{I}^{-}+\mathrm{X}^{-}=\mathrm{SO}_{2}-\mathrm{X}^{-}+\mathrm{I}^{-}
$$




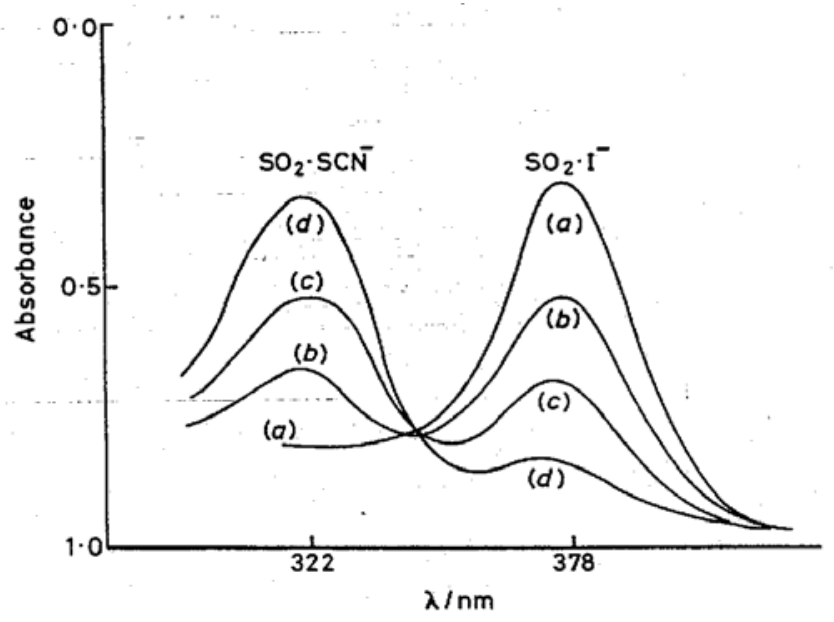

Figure 6. Replacement of $\mathrm{I}^{-}$by $\mathrm{SCN}^{-}$in $\mathrm{MeCN}$

a) $\mathrm{No} \mathrm{SCN}^{-}$, b) $\left.\left.\left[\mathrm{SCN}^{-}\right] /\left[\mathrm{I}^{-}\right]=0.4, \mathrm{c}\right)\left[\mathrm{SCN}^{-}\right] /\left[\mathrm{I}^{-}\right]=1, \mathrm{~d}\right)\left[\mathrm{SCN}^{-}\right] /\left[\mathrm{I}^{-}\right]=2$

In Figure 6 the gradual addition of $\mathrm{SCN}^{-}$solution causes a gradual disappearance of the $\mathrm{SO}_{2}-\mathrm{I}^{-}$peak at $378 \mathrm{~nm}$ and appearance of a new peak at $322 \mathrm{~nm}$ for the $\mathrm{SO}_{2}-\mathrm{SCN}^{-}$species. Table 15 includes the results of the above replacement reactions.

Table 15. Replacement Reactions in $\mathrm{MeCN}$, dmso and Water at $298^{\circ} \mathrm{K}^{*}$

\begin{tabular}{|c|c|c|}
\hline (a) In $\mathrm{MeCN}$ & $\begin{array}{l}\text { Reaction } \\
\text { 1) } \mathrm{Cl}^{-}+\mathrm{SO}_{2}-\mathrm{I}^{-} \\
\text {2) } \mathrm{Cl}^{-}+\mathrm{SOCl}_{2}-\mathrm{I}^{-} \\
\text {3) } \mathrm{Cl}^{-}+\mathrm{SO}_{2} \mathrm{Cl}_{2}-\mathrm{I}^{-}\end{array}$ & $\begin{array}{l}{\left[\mathrm{Cl}^{-}\right]:\left[\mathrm{I}^{-}\right]} \\
0.05(5), 0.10(8), 0.15(12), 0.20(15), 0.30(19), 0.40(23) \\
0.05(4), 0.10(7), 0.15(11), 0.20(15), 0.30(18), 0.40(22) \\
0.05(2), 0.10(3.5), 0.15(5.5), 0.20(8), 0.30(10), 0.40(12.5)\end{array}$ \\
\hline & $\begin{array}{l}\text { 4) } \mathrm{Br}^{-}+\mathrm{SO}_{2}-\mathrm{I}^{-} \\
\text {5) } \mathrm{Br}^{-}+\mathrm{SOCl}_{2}-\mathrm{I}^{-} \\
\text {6) } \mathrm{Br}^{-}+\mathrm{SO}_{2} \mathrm{Cl}_{2}-\mathrm{I}^{-}\end{array}$ & $\begin{array}{l}\quad\left[\mathrm{Br}^{-}\right]:\left[\mathrm{I}^{-}\right] \\
0.05(1.5), 0.10(3), 0.20(5), 0.30(8), 0.40(10) \\
0.05(2), 0.10(3.6), 0.20(5.8), 0.30(7.7), 0.40(9.3) \\
0.05(2.5), 0.10(4), 2.20(6), 0.30(8), 0.40(9.4)\end{array}$ \\
\hline & $\begin{array}{l}\text { 7) }[\mathrm{SCN}]^{-}+\mathrm{SO}_{2}-\mathrm{I}^{-} \\
\text {8) }[\mathrm{SCN}]^{-}+\mathrm{SO}_{2} \mathrm{Cl}_{2}-\mathrm{I}^{-}\end{array}$ & $\begin{array}{c}{\left[\mathrm{SCN}^{-}\right]:\left[\mathrm{I}^{-}\right]} \\
0.20(-), 0.50(2), 1.0(3), 2.5(4), 4.0(6) \\
0.20(-), 0.50(1.8), 1.0(2.9), 2.5(4), 4.0(5.9)\end{array}$ \\
\hline \multirow[t]{2}{*}{ (b) In dmso } & $\begin{array}{l}\text { Reaction } \\
\text { 9) } \mathrm{Cl}^{-}+\mathrm{SO}_{2}-\mathrm{I}^{-} \\
\text {10) } \mathrm{Cl}^{-}+\mathrm{SOCl}_{2}-\mathrm{I}^{-} \\
\text {11) } \mathrm{Cl}^{-}+\mathrm{SO}_{2} \mathrm{Cl}_{2}-\mathrm{I}^{-}\end{array}$ & $\begin{array}{l}\quad\left[\mathrm{Cl}^{-}\right]:\left[\mathrm{I}^{-}\right] \\
0.05(3), 1.0(5), 1.5(7), 2.0(10), 3.0(13), 4.0(17) \\
0.50(3), 1.0(4), 1.5(6), 2.0(9), 3.0(12), 4.0(15) \\
2.0(8), 4.0(16)\end{array}$ \\
\hline & $\begin{array}{l}\text { 12) } \mathrm{Br}^{-}+\mathrm{SO}_{2}-\mathrm{I}^{-} \\
\text {13) } \mathrm{Br}^{-}+\mathrm{SOCl}_{2}-\mathrm{I}^{-}\end{array}$ & $\begin{array}{c}{\left[\mathrm{Br}^{-}\right]:\left[\mathrm{I}^{-}\right]} \\
0.50(4), 1.0(6), 2.0(11), 4.0(13) \\
0.50(4), 1.0(5), 1.5(7), 2.0(10)\end{array}$ \\
\hline (c) In water & 14) $\mathrm{Cl}^{-}+\mathrm{SO}_{2}-\mathrm{I}^{-}$ & $4.0(3), 8.0(5), 12.0(7)$ \\
\hline
\end{tabular}

*No replacement was observed by $[\mathrm{SCN}]^{-}$in dmso. Percentage replacements of the iodide species are given in parentheses.

In all the above reactions the extent (or magnitude) of replacement depends on the stability constant for the reactant and product complex species. Table 16 includes the $\mathrm{K}_{\mathrm{c}}$ data for reactants and products in the 


\section{SALAMA and WASIF}

replacement reactions. Another factor which determines the magnitude of the replacement is the Lewis basic character of the ligands and a third factor appears to be related to the donor and acceptor number of the solvent used (Salama et al., 1971; Pearson, 1963; Day et al., 1969).

Table 16. Stability Constants for Reactants and Products in Replacement Reactions at $298^{\circ} \mathrm{K}$

\begin{tabular}{|l|l|l|l|l|}
\hline $\mathrm{X}^{-}$ & $\mathrm{Cl}^{-}$ & $\mathrm{Br}^{-}$ & $\mathrm{I}^{-}$ & $\mathrm{SCN}^{-}$ \\
\hline $\mathrm{SO}_{2}-\mathrm{X}^{-}$ & 372 & 160 & 38 & 65 \\
\hline $\mathrm{SOCl}_{2}-\mathrm{X}^{-}$ & 362 & 240 & 150 & 77 \\
\hline $\mathrm{SO}_{2} \mathrm{Cl}_{2}-\mathrm{X}^{-}$ & 10 & 41 & 77 & 298 \\
\hline
\end{tabular}

\subsection{Correlation of Stability Constants with Ligand Replacement}

\subsubsection{The $\mathrm{Cl}^{-} \mathrm{I}^{-}$Reaction}

The data in Table 15 show that in the presence of two halide ligands, $\mathrm{Cl}^{-}$and $\mathrm{I}^{-}$and acceptors such as $\mathrm{SO}_{2}, \mathrm{SOCl}_{2}$ and $\mathrm{SO}_{2} \mathrm{Cl}_{2}$ in $\mathrm{MeCN}$ solvent the thermodynamics would be more favorable for $\mathrm{SO}_{2}-\mathrm{Cl}^{-}$and $\mathrm{SOCl}_{2}-\mathrm{Cl}^{-}$than for $\mathrm{SO}_{2}-\mathrm{I}^{-}$and $\mathrm{SOCl}_{2}-\mathrm{I}^{-}$. We may add that $\mathrm{K}_{\mathrm{c}}\left(\mathrm{SO}_{2}-\mathrm{Cl}^{-}\right)$is nearly equal to $\mathrm{K}_{\mathrm{c}}\left(\mathrm{SOCl}_{2}-\mathrm{Cl}^{-}\right)$and both are much higher than $\mathrm{K}_{\mathrm{c}}\left(\mathrm{SO}_{2} \mathrm{Cl}_{2}-\mathrm{Cl}^{-}\right)$in the ratio 37: 36: 1. Such a large difference in stability constants makes replacement of $\mathrm{I}^{-}$by $\mathrm{Cl}^{-}$much easier for $\mathrm{SO}_{2}-\mathrm{I}^{-}$and $\mathrm{SOCl}_{2}-\mathrm{I}^{-}$than it is for $\mathrm{SO}_{2} \mathrm{Cl}_{2}-\mathrm{I}^{-}$. The data in Table 15 and the plot of Figure 7 illustrate this observation and we note that the percentage replacement in $\mathrm{SO}_{2}-\mathrm{I}^{-}$and $\mathrm{SOCl}_{2}-\mathrm{I}^{-}$fall at a low $\left[\mathrm{Cl}^{-}\right] /\left[\mathrm{I}^{-}\right]$on the same line and are much higher for $\mathrm{SO}_{2} \mathrm{Cl}_{2}-\mathrm{I}^{-}$. The replacement reaction, equation (6), seems anomalous in view of the $\mathrm{K}_{\mathrm{c}}\left(\mathrm{SO}_{2} \mathrm{Cl}_{2} \mathrm{I}^{-}\right) / \mathrm{K}_{\mathrm{c}}\left(\mathrm{SO}_{2} \mathrm{Cl}_{2}-\mathrm{Cl}^{-}\right)$ratio $=$ 8. That this reaction, equation (6), can take place despite the reversed order of stability constants for reactant and product can only be due to the relative abundance of the $\mathrm{Cl}^{-}$ligand which seems to outweigh the difference in stability constants. Table 15 shows that a $20 \%$ disappearance of $\mathrm{SO}_{2}-\mathrm{I}^{-}$requires a ligand ratio of $0.35: 1$ while in the case of $\mathrm{SO}_{2} \mathrm{Cl}_{2} \mathrm{I}^{-}$ligand ratio $\left[\mathrm{Cl}^{-}\right] /\left[\mathrm{I}^{-}\right]=1: 1$ was necessary for the same percentage replacement. By changing the ligand ratio we are merely increasing the chances of effective collisions leading to a replacement by the more abundant ligand.

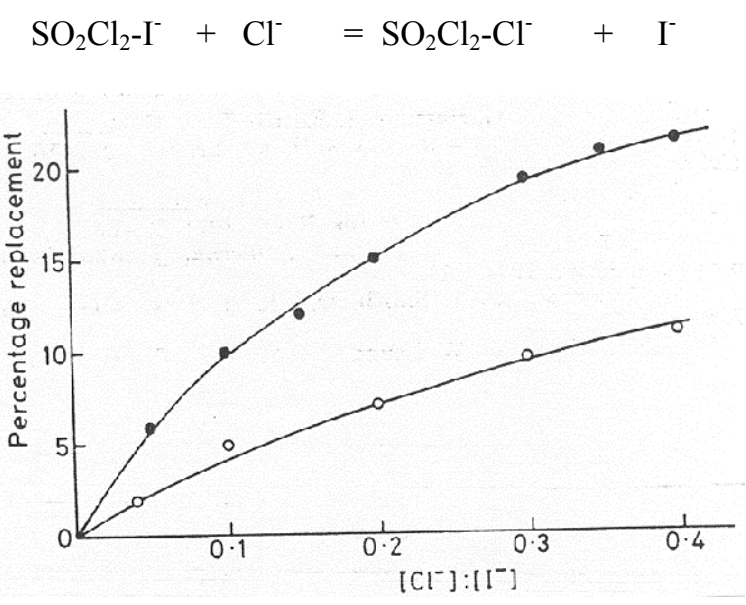

Figure 7. Comparison of Replacement Reactions by added $\mathrm{Cl}^{-}$in $\mathrm{MeCN}$ at $298^{\circ} \mathrm{K}$ (•) $\mathrm{SO}_{2}-\mathrm{I}^{-}$and $\mathrm{SOCl}_{2}-\mathrm{I}^{-}$; (o) $\mathrm{SO}_{2} \mathrm{Cl}_{2}-\mathrm{I}^{-}$ 


\section{WEAK COMPLEXES OF SULFUR COMPOUNDS}

\subsubsection{The $\mathrm{Br}^{-}-\mathrm{I}^{-}$and $\mathrm{SCN}^{-}-\mathrm{I}^{-}$Reactions}

The magnitudes of replacement for the ligands $\mathrm{Br}^{-}$and $\mathrm{SCN}^{-}$are not widely different (Table 15). This is not unexpected since the stability constants for $\mathrm{SO}_{2}-\mathrm{Br}^{-}, \mathrm{SOCl}_{2}-\mathrm{Br}^{-}$and $\mathrm{SO}_{2} \mathrm{Cl}_{2}-\mathrm{Br}^{-}$are in the ratio 4:6:1 and for $\mathrm{SO}_{2}-\mathrm{SCN}^{-}$and $\mathrm{SOCl}_{2}-\mathrm{SCN}^{-}$and $\mathrm{SO}_{2} \mathrm{Cl}_{2}-\mathrm{SCN}^{-}$are in the ratio 1:1.2:2.4. Figure 8 shows a comparison of the replacing ability of the $\mathrm{SCN}^{-}$ligand with that of $\mathrm{Cl}^{-}$and $\mathrm{Br}^{-}$ligands. The replacing ability of ligands fall in order $\mathrm{Cl}^{-}>\mathrm{Br}^{-}>\mathrm{SCN}^{-}$, which parallels their Lewis base character as hard, borderline and soft respectively (Pearson, 1963; Day et al., 1969).

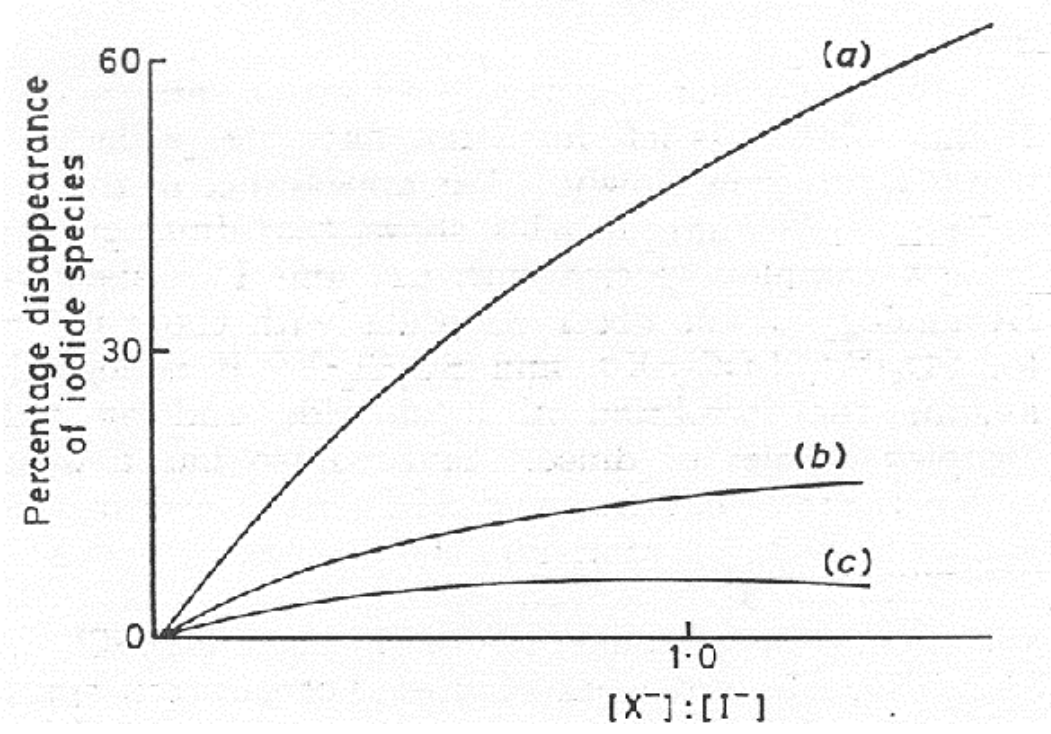

Figure 8. Comparison of Amounts of Replacements of $\mathrm{I}^{-}$in $\mathrm{SOCl}_{2}-\mathrm{I}^{-}$

\subsection{The Role of Solvents in Replacement Reactions}

Table 15 and Figure 9 show the effect of solvents on the reaction $\mathrm{SO}_{2}-\mathrm{I}^{-}+\mathrm{X}^{-}$where $\mathrm{X}^{-}=\mathrm{Cl}^{-}$. For a ligand ratio $\left[\mathrm{Cl}^{-}\right] /\left[\mathrm{I}^{-}\right]=4$ the extent of replacement is $70 \%$ in MeCN but only $16 \%$ in dmso and less than $2 \%$ in water. Clearly a change of solvent greatly affects the degree of replacement.

In dmso two factors are operative: a) dmso may solvate the $\mathrm{Cl}^{-}$ligand and b) dmso may act as a potential acceptor at its $\mathrm{S}$ atom and compete with $\mathrm{SO}_{2}$ in solution. The conclusion that dmso acts as a potential acceptor was reached using the observation of the spectrum of a solution containing $\mathrm{Cl}^{-}$and $\mathrm{I}^{-}$ ligands. This solution shows slow growth of two peaks at $292 \mathrm{~nm}$ and $365 \mathrm{~nm}$ and the rate of peaks growth depends on the ligand concentration and a rate constant was found to be $2 \times 10^{-2} \mathrm{~min}^{-1}$ at $298^{\circ} \mathrm{K}$.

The replacement reaction $\mathrm{SO}_{2}-\mathrm{I}^{-}+\mathrm{Cl}^{-}=\mathrm{SO}_{2}-\mathrm{Cl}^{-}+\mathrm{I}^{-}$in dmso is ionic with a rate constant of $10^{10} \mathrm{sec}^{-1}$ and therefore the addition of $\mathrm{Cl}^{-}$to $\mathrm{SO}_{2}-\mathrm{I}^{-}$in dmso is accompanied by the disappearance of the peak at $378 \mathrm{~nm}\left(\mathrm{SO}_{2}-\mathrm{I}^{-}\right)$and the emergence of the new peak at $292 \mathrm{~nm}\left(\mathrm{SO}_{2}-\mathrm{Cl}^{-}\right)$. If this solution is left for some time the peaks at $292 \mathrm{~nm}$ and $365 \mathrm{~nm}$ will slowly appear for the complex species of dmso with $\mathrm{Cl}^{-}$and $\mathrm{I}^{-}$ ligands respectively. The sulfur atom in dmso will be the acceptor center with the following structures: $\mathrm{OMe}_{2} \mathrm{~S}-\mathrm{Cl}^{-}$and $\mathrm{OMe}_{2} \mathrm{~S}-\mathrm{I}^{-}$respectively.

Recent work on photoelectron spectroscopy of sulfur compounds favors this view (Guest et al., 1972; Buncel et al., 1975). Water appears to be a more drastic solvating agent towards the $\mathrm{Cl}^{-}$ligand which results in a low degree of replacement with high ligand ratio of $\left[\mathrm{Cl}^{-}\right] /\left[\mathrm{I}^{-}\right]=12$. 


\section{SALAMA and WASIF}

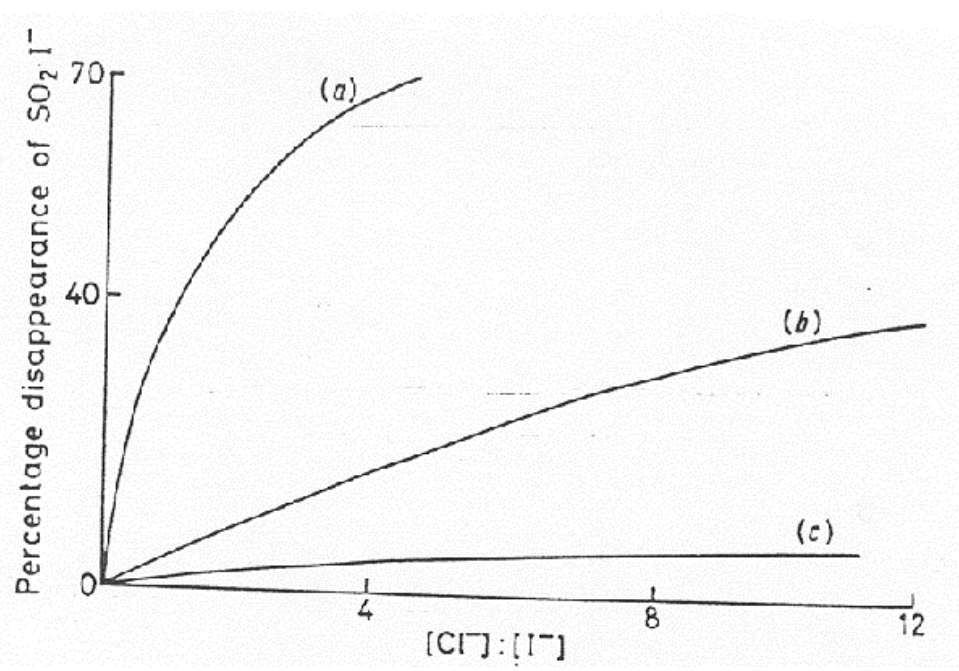

Figure 9. Effect of Solvents on the Reaction $\mathrm{SO}_{2}-\mathrm{I}^{-}+\mathrm{Cl}^{-} \rightarrow \mathrm{SO}_{2}-\mathrm{Cl}^{-}+\mathrm{I}^{-}$ in a) $\mathrm{MeCN}$, b) dmso and c) water at $298^{\circ} \mathrm{K}$.

\subsection{Replacement Reactions in Mixed Solvents}

Table 17 includes the replacement reaction data for the $\mathrm{SO}_{2}-\mathrm{I}^{-}+\mathrm{Cl}^{-}$reaction in MeCN-dmso mixed solvent. For all runs the ligand ratio was $\left[\mathrm{Cl}^{-}\right] /\left[\mathrm{I}^{-}\right]=4$. The replacement percentage of iodide is given in parentheses. As the percentage of dmso in the solvent increases the ability of $\mathrm{Cl}^{-}$to replace $\mathrm{I}^{-}$diminishes. Here it is possible that the solvating power of dmso towards $\mathrm{Cl}^{-}$makes it sterically difficult to replace the $\mathrm{I}^{-}$in $\mathrm{SO}_{2}-\mathrm{I}^{-}$.

Table 17. Replacement Reaction of $\mathrm{SO}_{2}-\mathrm{I}^{-}+\mathrm{Cl}^{-}$in $\mathrm{MeCN}$-dmso Mixture at $298^{\circ} \mathrm{K}$

\begin{tabular}{|l|l|l|l|l|l|}
\hline $\mathrm{dmso} \%$ & $0.00(70 \%)$ & $25(53 \%)$ & $50(32 \%)$ & $75(20 \%)$ & $100(17 \%)$ \\
\hline
\end{tabular}

\section{Structure of $\mathrm{SO}_{2}-\mathrm{X}^{-}$}

The structures of $\mathrm{SO}_{2}-\mathrm{X}^{-}\left(\mathrm{X}^{-}=\mathrm{F}, \mathrm{Cl}, \mathrm{Br} \& \mathrm{I}\right)$ (Latajka et al., 1995) were investigated using ab initio method at the electron correlation level with effective core potential double zeta valence basis set with polarization functions. It has been found that the minimum on the potential energy surface corresponds to the $\mathrm{C}_{\mathrm{S}}$ structure of the complexes whereas the planar $\mathrm{C}_{2 \mathrm{~V}}$ structure is the transition state for the inversion process. The stability of $\mathrm{SO}_{2}-\mathrm{X}^{-}$complexes fall in the order $\mathrm{SO}_{2}-\mathrm{F}^{-}>\mathrm{SO}_{2}-\mathrm{Cl}^{-}>\mathrm{SO}_{2}-\mathrm{Br}^{-}>\mathrm{SO}_{2}-\mathrm{I}^{-}$.

Careful studies of the potential energy surfaces of the complexes clearly indicates that only one structure corresponds to the minimum. The $\mathrm{X}^{-}$is in close contact with the $\mathrm{S}$ atom having a positive total charge. The intermolecular distance $\mathrm{R}(\mathrm{S} \ldots . . \mathrm{X})$ increases in this series with the increase of the atomic number of $\mathrm{X}$. The shortest intermolecular distance is noted for $\mathrm{SO}_{2}-\mathrm{F}^{-}$complex. Replacement of $\mathrm{F}^{-}$by $\mathrm{Cl}^{-}$ increases the distance by $2.61 \AA$ and successive replacements by $\mathrm{Br}^{-}$and $\mathrm{I}^{-}$ligands cause an increase in $\mathrm{R}(\mathrm{S} \ldots . . \mathrm{O})$ value by about $0.3 \AA$.

The complex formation slightly distorts the $\mathrm{SO}_{2}$ subunit. The $\mathrm{SO}$ bond is stretched while the OSO bond angle slightly decreases in comparison with the values for the isolated $\mathrm{SO}_{2}$ subunit. Perturbation of the geometrical structure of the $\mathrm{SO}_{2}$ subunit is essentially pronounced with the $\mathrm{F}^{-}$ligands. 


\section{WEAK COMPLEXES OF SULFUR COMPOUNDS}

$\mathrm{SO}_{2}-\mathrm{X}^{-}$complexes are not planar and have $\mathrm{C}_{\mathrm{S}}$ symmetry. The nonplanarity of the complex is denoted by $\alpha$ which measures the angle between the $\mathrm{C}_{2}$ axis of the $\mathrm{SO}_{2}$ subunit and the $\mathrm{S} \ldots \mathrm{X}$ axis. In the series of $\mathrm{SO}_{2}-\mathrm{X}^{-}$complexes the angle decreases from $71^{\circ}$ for the $\mathrm{SO}_{2}-\mathrm{F}^{-}$complex to $61^{\circ}$ for the $\mathrm{SO}_{2}-\mathrm{I}^{-}$complex which makes this complex less pyramidal.

Since in this series the intermolecular distance has increased from $1.93 \AA$ for the $\mathrm{SO}_{2}-\mathrm{F}^{-}$complex to $3.25 \AA$ for the $\mathrm{SO}_{2}-\mathrm{I}^{-}$complex, the dipole-charge interaction becomes most important and in consequence the $\mathrm{SO}_{2}-\mathrm{I}^{-}$is less pyramidal.

In conclusion we may report that $\mathrm{SO}_{2}-\mathrm{F}^{-}$has a rigid pyramidal structure while $\mathrm{SO}_{2}-\mathrm{I}^{-}$is the least pyramidal in the above series of $\mathrm{SO}_{2}-\mathrm{X}^{-}$complex species.

\section{Conclusion}

The formation of the complex species $\mathrm{SO}_{2}-\mathrm{X}^{-}, \mathrm{SOCl}_{2}-\mathrm{X}^{-}, \mathrm{SO}_{2} \mathrm{Cl}_{2}-\mathrm{X}^{-}$and $\mathrm{SOBr}_{2}-\mathrm{X}^{-}$where $\left(\mathrm{X}^{-}=\mathrm{Cl}^{-}\right.$, $\mathrm{Br}^{-}, \mathrm{I}^{-}$and $\mathrm{SCN}^{-}$) was reported during the last thirty years.

The above complexes are weak of charge transfer nature and can not be isolated from solution but can be detected by spectrophotometry. Their enthalpies of formation $\Delta \mathrm{H}_{\mathrm{f}}{ }^{\mathrm{o}}$ vary between -22.5 and $-6.0 \mathrm{~kJ} / \mathrm{mol}$. The stabilities of the above complexes depend on the solvent used, the acceptor properties of the $\mathrm{S}_{\text {compound }}$, the basic nature of the halide ligands and the temperature of the system.

Ligand replacements of the following type:

$$
\mathrm{SO}_{2}-\mathrm{I}^{-}+\mathrm{Cl}^{-} \rightarrow \mathrm{SO}_{2}-\mathrm{Cl}^{-}+\mathrm{I}^{-}
$$

showed that the reaction is quite fast $10^{10} \mathrm{~s}^{-1}$ (detectable by Laser Technique) and is universal throughout all the complex species studied.

The geometry of $\mathrm{SO}_{2}-\mathrm{X}^{-}$species suggest a pyramidal type with acute angle for $\mathrm{X}^{-}=\mathrm{Cl}^{-}$and less for $\mathrm{X}^{-}=\mathrm{I}^{-}$.

\section{References}

AMIS, E. S. 1965. Effect of Solvent on Reaction Rates, Academic Press, London.

ANDREW, L. J. and KEEFER, R. M. 1961. Molecular complexes of halogens, Adv. Inorg. Chem. Radiochem., 3: 91-131.

ASMUS, E. 1960. Determination of the composition of weak complexes, Z. Analyt. Chem., 178: 104-116.

BASOLO, F. and PEARSON, R. G. 1958. Mechanisms of Inorganic Reactions, Wiley, New York.

BELL, R. P. 1965. The Proton in Chemistry, Methuen, London.

BENESI, H. A. and HILDERBRAND, J. 1949. A spectrophotometric investigation of the interaction of iodine with aromatic hydrocarbons, J. Amer. Chem. Soc., 71: 2703-2707.

BENSON, R. 1960. The Foundations of Chemical Kinetics, McGraw Hill, New York.

BUNCEL, E. and LEUNG, H. W. 1975. Catalysis by tertiary amines of $\sigma$ - complex formation between 1,3,5 trinitrobenzene and aniline, J. C. S. Chem. Comm : 19-20.

BURKE, T. G. and SMITH, D. F. 1959. HF-SO 2 and similar vapor-phase complexes, J. Mol. Spectroscopy 3: 381-385.

BUROW, D. F. 1970. Internal-reflection spectroscopy of non-aqueous solvent systems: Halides in liquid sulfur dioxide, Develop. Appl. Spectrosc., 7B: 111-113.

CHADWICK, D., FROST, D. C., HERRING, F. G. and MCLEAN, R. A. N. 1973. Photoelectron spectra of sulfuryl and thionyl halides, Canad. J. Chem., 51: 1893-1905.

DAY, M. C. and SELBIN, J. 1969. Theoretical Inorganic Chemistry, Reinhold and Winston, New York.

DRAGO, R. S. 1959. Molecular addition compounds of iodine. An absolute method for the spectrophotometric determination of equilibrium constants, J. Amer. Chem. Soc., 81: 6138-6141.

FRIEDMAN, L. and WETTER, W. P. 1967. Purification of thionyl chloride, J. Chem. Soc., (A): 36-37. 
FROST, A. A. and PEARSON, R. G. 1961. Kinetics and Mechanisms, Wiley, New York.

GOULD, E. S. 1960. Inorganic Reactions and Structure, Holt Reinhart, and Winston, New York.

GRUNWALD, E. 1951. The correlation of solvolysis rates and the classification of solvolysis reactions into mechanistic categories, J. Amer. Chem. Soc., 73: 2700-2707.

GUEST, M. F., HILLIER, H. I. and SAUNDERS, V. R. 1972. Ab initio calculations in extended bases and localized orbital calculations of the bonding in $\mathrm{SO}_{2}$ and $\mathrm{PF}_{3}$, J. Chem. Soc., Farad.II: 114-120.

GUTMANN, V. 1956. Reactions in some non-aqueous ionizing solvents, Quart. Rev., 10: 451-462.

GUTMANN, V. 1967. Principals of Coordination Chemistry, in Non-Protonic solutions, $1^{\text {st }}$ Conference on Non-Aqueous Solvents, McMaster University, Hamilton, Canada.

GUTMANN, V. 1971. Phenomenological Approach to Cation-Solvent Interaction, $3^{\text {rd }}$ Conference on NonAqueous Solvents, Michigan State University, East-Lansing, Michigan, USA.

JANDER, G. and RUPPOLT, W. 1937. The solubility of inorganic substances in liquid sulfur dioxide, $Z$. Physik. Chem., A, 179: 43-51.

JANDER, J. and TUERK, G. 1962. Preparation of solid 1-diiodo-1-hydrogen sulfide, Chem. Ber. 95: 881$888 ; 1963$. Spectrophotometric proof of charge transfer complexes of the acceptor $\mathrm{SO}_{2}$ with the donors iodide ion and iodine, Ingew. Chem., 75 (16/17) : 792-796.

JOB. P. 1928. Formation and stability of inorganic complexes in solution, Ann. Chim., 9: 113-203.

KETELAAR, J. A. A., VAN De STOPPE, C. GOUDSMIT, A., and DZCUBAS, W. 1952. Spectrophotometric study of the solvation of iodine in dioxan solution II, Rec. Trav. Chim., 71: 11041114.

LATAJKA, Z., RATAJCZAK, H., WASIF, S. and SALAMA, S. B. 1995. Structure and energetics of $\mathrm{SO}_{2^{-}}$ $\mathrm{X}^{-}$(X = F, Cl, Br, I) complexes, J. Mol. Str., Theochem, 333: 291-296.

MINES, G. W., THOMAS, R. K., and THOMPSON, H. T. 1972. Photoelectron spectra of compounds containing thionyl and sulfuryl groups, Proc. Roy. Soc., A329: 275-282.

PEARSON, R. G. 1963. Hard and soft acids and bases, J. Amer. Chem. Soc., 85: 3533-3539.

ROSSOTTI, F. J. C. and ROSSOTTI, H. 1961. The Determination of Stability Constants, McGraw Hill, New York.

SALAMA, A., SALAMA, S. B., SOBEIR M., and WASIF, S. 1971. Complex species of $\mathrm{SO}_{2}, \mathrm{SOCl}_{2}$, $\mathrm{SO}_{2} \mathrm{Cl}_{2}$ with chloride, bromide, and iodide ions, J. Chem. Soc. (A): 1112-1117.

SALAMA, S. B. and WASIF, S. 1973. Complex species of $\mathrm{SO}_{2}, \mathrm{SOCl}_{2}$, and $\mathrm{SO}_{2} \mathrm{Cl}_{2}$ with the thiocyanate ligand, J. Chem. Soc., Dalton: 2148-2150.

SALAMA, S. B. and WASIF, S. 1975. Effect of solvent on the stability of 1:1 complexes of sulfur dioxide, sulphinyl dichloride, and sulphonyl dichloride with halogen ions, J. Chem. Soc., Dalton: 151-153.

SALAMA, S. B., WASIF, S., and KHAN, M. A. 1978. Halide-ion replacement in 1:1 complexes of sulfur dioxide, thionyl chloride, and sulphonyl chloride with halide ions in acetonitrile and dimethylsulfoxide, J. Chem. Soc., Dalton: 915-918.

SALAMA, S. B., WASIF, S. and OMER, M. M. 1978. Stability constants of the weak 1:1 complexes of sulfur dioxide, thionyl chloride, and sulphonyl chloride with halide ions in the mixed solvent acetonitrile-dimethylsulfoxide at $25^{\circ} \mathrm{C}, \mathrm{J}$. Chem. Soc., Dalton: $918-920$.

SALAMA, S. B. and WASIF, S. 1985. Weak complexes of sulfur and selenium oxo species. A thermodynamic view on solvent effects in mixed solvents, Arab Gulf J. of Sc. Res., 3(1): 121--131.

SALAMA, S. B. and WASIF, S. 1991. Weak complexes of sulfur complex species between iodide ions and dimethylsulfoxide, International Jour. Chem., 2(4): 149-154.

SALAMA, S. B. and WASIF, S. 1994. Formation of iodide ions with some arenesulfonyl chloride, Asian Journal of Chemistry, 6(2): 381-388.

SANDHU, S. S. and SINGH, A. 1960. Complexes of solvacids and ansolvo bases, J. Indian Chem. Soc. 37: 329-333.

SANDHU, S. and SINGH, A. 1962. Mechanism of the reactions of solvo-bases and solvo-acids, J. Indian Chem. Soc . 39: 589-594. 


\section{WEAK COMPLEXES OF SULFUR COMPOUNDS}

SEEL, F. and RIEHL, L. 1955a. Fluorosulfinates, Z. anorg. Chem., 282: 293-306.

SEEL, F. and RIEHL, L. 1955b. Fluorosulfinates, Angew. Chem., 67: 32-33.

WADDINGTON, T. C. 1965. Non-Aqueous Solvent Systems, Academic Press, London.

WASIF, S. Unpublished Work.

WITECKOWA, S. and WITOK, T. 1955. Reaction between iodine and sulfur dioxide, Zeszyty nauk, Politech lodz.Chem.Spoz., 1: 73-86.

Received 12 December 1999

Accepted 24 June 2000 